\title{
Relationship of Nurse Manager's Practices with Nurse's Retention and Quality of Care Among Registered Nurses in Public Hospital Lahore
}

\author{
Farzana Parveen ${ }^{1 *}$, Muhammad Hussain ${ }^{2}$, Muhammad. Afzal ${ }^{3}$,Syed Amir Gilani ${ }^{4}$ \\ 1.BSN Student, Lahore School of Nursing, The University of Lahore, Pakistan \\ 2.Assistant Professor, Lahore School of Nursing, The University of Lahore, Pakistan \\ 3.Associate Professor, Lahore School of Nursing, The University of Lahore, Pakistan \\ 4.Professor, The University of Lahore, Pakistan
}

\begin{abstract}
Back ground of the study: Nurse Manager's practices play a vital role in nursing retention and promotion of best care in nursing. Improved the nursing retention will prompt reserve the organization, which may additionally be allocated to activities, for example preparing and mentorship to help nurse managers in making these imperative management capabilities. Approaches also want to be set up to ensure that nurse managers accomplish adequate organizational support from nursing administrators (C. M. Duffield, Roche, Blay, \& Stasa, 2011). In Pakistan, the nursing profession has been experiencing a workforce shortage staff in recent years, making nurses a precious resource. The substantial low retention of nurses is mainly due to their intent to leave, absenteeism. The work-life issues threatening retention of nurses and quality of care are serious concern for health administrators (Hamid, Malik, Kamran, \& Ramzan, 2014). Objectives: To assess the Relationship of Nurse manager's practices with nurse's retention and quality of care in Public Hospital of Lahore. Methodology: A quantitative descriptive cross sectional study was conducted to assess the relationship of nurse manager's practices with nurse's retention and quality of care. The instrument use for the data collection was adopted questioner and convenient sampling technique was used. Conclusion: The present study is considered as a cornerstone that gives strong support towards understanding of nurses' manager's practices and their retention. It highlighted that a significant difference was found between management practices with nurse' retention and patient care. These results substantiate the belief that aspects of the practice environment affect staff nurse retention, and most importantly, the quality of care delivered on hospital nursing units.
\end{abstract}

Keywords: Quality; Care; Retention; Nurse Manager..

DOI: $10.7176 / \mathrm{JHMN} / 94-02$

Publication date:October $31^{\text {st }} 2021$

\section{Introduction}

\section{1)Background:}

Nurses are one of the most valuable resources to the health care organizations, but the nursing profession is facing major challenges such as a growing intent to leave, absenteeism and medication errors. This impacts the quality of patient care they give. Nurses comprise the greatest part of total health care workers globally, as 24 hours caregivers are essential for ensuring quality patient care (Heidari, Seifi, \& Gharebagh, 2017). Nursing is a profession in which the practitioner applies knowledge with skills and attitudes in the provision of comfort and care for the health needs of people. It is a dynamic, therapeutic and educational process by which the practitioner promotes health, prevents illness and participates in curative and rehabilitative services to individuals, families and communities (Parahoo, 2014). Nurse Managers means a person who keeps the responsibility to bring positive changes in the clinical environment. Nurse Managers want to utilize management characteristics to undertake the responsibility. Now a day, responsibility of Nurse Managers emerge as greater vital than constantly due to needs forexplanation, fee cuttings, improvements in therapeutic skill, and concentrated measurements of hospital stay for the improvement of profession (McGuire \& Kennerly, 2006). Nurse Managers should be idealized in their daily practice because it improved the quality of care and nursing retention. Therefore, Nurse Managers should be arrange meeting with organization for workshop and symposium to improve the practice of registered nurses for evidence base practice in clinical site (Ulrich et al., 2010). Hence, Nurse Mangers under the supervision of the head of department, play an imperative role in retaining nurses through utilizing their administrative and authority skills to make a positive culture that leads retention (El-Jardali, Dimassi, Dumit, Jamal, \& Mouro, 2009). Furthermore, the World Health Organization (WHO) indicates that the nurse manager's practice is an important factor in the retention of health professionals (intent to leave, absenteeism) affect the quality of care both directly and indirectly. Addressing the nurse manager's practice, therefore, plays a critical role in ensuring both the supply of a health workforce as well as the enhancement, effectiveness and motivation of that workforce (Lambrou, Merkouris, Middleton, \& Papastavrou, 2014). In Pakistan, the nursing profession has been experiencing a workforce shortage staff in recent years, making nurses a precious resource. The substantial low retention of nurses 
is mainly due to their intent to leave, absenteeism. The work-life issues threatening retention of nurses and quality of care are serious concern for health administrators (Hamid, Malik, Kamran, \& Ramzan, 2014). Study was conducted in china, $40.4 \%$ nurses intended to leave their current nursing position. Therefore, it is important to determine the factors influencing the nurse's desire to remain, hence eliminate the nurse intention to leave and absenteeism. Organizational and personal factors together can be used to predict the rate of nurses considering leaving their current position. On the organization level, work support, such as the flexible schedule, career advancement opportunities has shown to way directly the nurses from leaving their position. Furthermore, other studies also found a correlation between the employee-driven career growth within the organization and retention rate most likely due to increase in quality of care in hospital (Yang, Liu, Liu, \& Zhang, 2015). Study was conducted in United States, more Registered Nurses left their first nursing job (26\%) than nursing profession (2\%) during the first one or two years in your career due to poor management in hospital setting. Moreover, in the West study, rate of leaving nursing profession for a better job was highest (Flinkman, Isopahkala-Bouret, \& Salanterä, 2013). Good Nurse Manager's practices play a vital role in nursing retention and promotion of best care in nursing. Improved the nursing retention will prompt reserve the organization, which may additionally be allocated to activities, for example preparing and mentorship to help nurse managers in making these imperative management capabilities. Approaches also want to be set up to ensure that nurse managers accomplish adequate organizational support from nursing administrators (C. M. Duffield, Roche, Blay, \& Stasa, 2011). High rates of nurse turnover remain problematic for employers and impact the quality of patient care. In particular, the 30-60\% turnover of new graduate nurses impacts the ability of organizations to deliver quality, cost-effective patient care (Finkler, Kovner, \& Jones, 2007). While there are multiple predictors of turnover and expressed intent to leave, incivility has been demonstrated to exert a significant influence (Wong, Spence Laschinger, \& Cummings, 2010). Therefore, active Nurse Manager gives direction to solving complicated issues which have been identified during nursing care delivery. Moreover, Nurse Managers make a plan to encourage the Registered Nurses according to their implementation in workplace. With a coming near, lack of nursing managers compounded by the current lack of nurses, it is gradually imperative to locate approaches to improve and continue nursing managers to make sure high quality care in the hospital settings. Developing nursing managers and employing and nursing retention into management positions are necessary mechanisms of progression organization for future nursing management. Hospitals settings spend huge assets each and every year on employees and management development, so understanding the factors that make contributions to nursing management is important (Wong, Cummings, \& Ducharme, 2013). Nurse Manager practices that directly or indirectly affects retention of staff and quality of care outcomes. Kouzes and Posner, have defined five leadership practices that have been used in nursing research. The five practices are; trial the procedure, Empower others to act, Inspire mutual vision, Encourage feelings and Model the way (Kouzes \& Posner, 2001). The role of the nursing unit manager is vital to retention of staff. Nurses appreciate good leaders. These positions can impact positively or negatively on nurse recruitment and retention. Laschinger, Wong, McMahon, and Kaufmann found strong nurse leaders created environments for "work effectiveness" that impacted on nurse recruitment and retention through promotion of autonomous practice and participatory decision-making. The nurse participants felt empowered when their leaders provided "purpose and meaning to their work' 'C. Duffield, Roche, O'Brien-Pallas, Catling-Paull, \& King, 2014). Nurse retention is an imperative role to examine from a financial function as properly as from a nursing best care view. Some of the reasons recognized through nurses for leaving their nursing profession are directly related to affected person safety and staffing issues (Hughes, 2017). The World Health Organization has recognized nurse retention as a worldwide priority, as both developed and developing countries face a nursing workforce shortage such as intent to leave. Given reports of turnover rates as high as $60 \%$ in the $1^{\text {st }}$ year of employment and combined with the shortage of nursing, it is important for health managers to understand the factors that contribute to new graduate nurse retention. The reasons that trigger nurses' intentions to leave are still unclear (Källander et al., 2013). A well clinical practices work situation, in which managers give the arrangement, performs, structures, strategies that allow clinical caretakers to cooperate in their work approaches, associations important to protected and improved quality of care (Phaneuf, 1976). Nurses have an essential part not just as care providers however additionally arrange and need to manipulate the environment in which enhancing quality of care is given. Nursing retention is a documented problem for the hospital settings, as evidenced by the several researches attempted with concern to the reasons why nurses leave their profession. Nurses' retention is estimated by the amount of staff nurses that continue to be with managers for a given period. Managers who retain nurses begin by using shared clear opportunities to the nurse. All these supervisors provide everyday input which is influence on nurses feel regard. When the nurses finalizes an conversation with a supervisor who keeps staff, she feels engaged, authorized, and assured in his or her capability to develop the job carried out (Nassar, Abdou, \& Mohmoud, 2011). Absenteeism among staff nurses leads to a reducing the retention of nurses and quality of patient care, an increased staff shortage in health care organization, increased workload, work-related stress, which adversely affects their confidence and a lack of motivation among staff nurses. It affects the working environment and the financial performance of a hospital. Also, absenteeism is a side effect of personnel problems, Ineffective management such as, poor practices 
of nurse manager, poor working relationships, lack control over decisions and overwork are contributing factors. Absenteeism has been an effect on the working condition of the staff nurses (Mudaly \& Nkosi, 2015). Medication error is a global issue that can cause serious harm and even death. Nurses who are responsible for administering medication at the patient interface have the potential to contribute to the problem by making medication administration errors or preventing errors before medication is given (Alreshidi, 2016). Drug administration error on the health care wards is a chronic issue and its events a real so recurrent. Administering medication is possibly the most elevated challenge a nurse can achieve, a chance can prompt to disturbing values for the patient and for the nurse's profession. Drug error in hospitals is frequently allocated with by means of random and unproductive incomes, with poor information of the influences the error occurs. Usually, individual nurses are in reality blamed for their inattention. By concentrating on the individual, the whole arrangement of contributing factors can not be known. Rather, ineffective efforts will be complete to exchange human behaviorone of the most change-safe parts of any arrangement (Anderson \& Webster, 2001). A medication error is any preventable event that may cause or lead to inappropriate medication use or patient harm while the medication is in the control of the healthcare professional, patient, or consumer Such events related to poor nurse manager's practice, healthcare products, procedures, and systems (Holmström, 2017). Quality of care in hospital setting is characterized as care that is given according to hospitals' requirements and job necessities. Factors of pleasant of nursing care include: suitable capabilities and records, caring approaches, high-quality communication, effective administrative and controlling organizations, effective community contribution, nursing records and records about patients' consequences symptoms (Mrayyan, 2006). Several patient consequences are not only partial through the common role play of separate care suppliers, however likewise by way of active of clinical groups and by way of more extensive organizational and monetary structures. Appropriate influences, for example, huge load of work or poor co-appointment systems, can be imperative prevention of wide-scale and maintainable development. Managerial changes could consequently supply fundamental mechanisms of quality change. Rights efficiency of administrative approaches for enhancing the best of care must be based on substantiation since demanding assessments (Wensing, Wollersheim, \& Grol, 2006). Quality of care is closely connected to the patient result in provided care; it is difficult to measure quality of care because every person is important. Quality of care is a degree of pleasure of providing the wellbeing care facilities for patients (Hughes, 2008). Results reflect a quality of care to patients, for example, the impact of correspondence amongst nurses and doctors may likewise have effective outcomes in patients' care (Shuldham, Parkin, Firouzi, Roughton, \& Lau-Walker, 2015)

\section{2) Gap Analysis \&Research problem;}

The nurse manager practices and nurse's retention and quality of care in the Health Care Organization are very important. Now a day, nurse manager requires leadership practices to effectively address the issues in the work environment, such as nursing retention (intent to leave absenteeism and change your profession) and quality of care in hospitals settings. Every day each hospital face shortage of staff, low quality of care and new inductive the staff every days. It might be happen due to low level of nurse manager's practices. Poor nurse manager practices leads to decrease the nursing retention, intent to leave, absenteeism, increasing medication errors and also affect the quality of care in hospitals settings. That's the problem which nurses face in hospital setting, that's why current study will help to improve the nurse manager practices and nursing retention and quality of care in hospital. In Pakistan, the nursing profession has been experiencing a workforce shortage staff in recent years, making nurses a precious resource. The substantial shortage of nurses is mainly due to their intent to leave, absenteeism. The work-life issues threatening retention of nurses and quality of care are serious concern for health administrators (Hamid et al., 2014).

In Belgian, $29.5 \%$ of nurses have an intention-to-leave the hospital. Patient-to nurse staffing ratios and nurse work environments are significantly $(\mathfrak{p}<0.05)$ associated with intention-to-leave. Interviews with Chief Nurse Officers revealed that high performing hospitals showing low nurse retention were in contrast to poor management practices and low performing hospitals characterized by flat health care organization structure with participative management style, structured education programs and career opportunities for nurses (Van den Heede et al., 2013). Many studies had conduct on determine the nurse manager practices and nurse's retention and quality of care in many areas of country, but no study will be conducted in Public Hospital in Pakistan. Therefore, I will conduct current study to assess the relationship of nurse manager's practice with nurse's retention and quality of care among registered nurses in public Sector Lahore.

\section{3) Research question;}

$>$ What are the relationships of nurse manager practices with nurse's retention and quality of patient care in wards of Punjab Institute of Cardiology, Lahore?

\section{4) Purpose of study;}

The purpose of this study was to assess the relationship of nurse manager practices with nurse's retention and 
quality care in Punjab Institute of Cardiology, Lahore.

\section{5) Hypothesis;}

\subsection{1) Hypothesis 1(H1, Ha);}

The nurse manager practices may have effect on the nurse's retention and quality of care in hospitals.

(H0);

The Nurse Manager's practices may not have effect on the nurse's retention and quality of care in nursing.

\subsection{2) Hypothesis 11}

(H1, Нa);

The nurse's retention and quality of care of nursing may have significant association with the nurse manager's practices.

(H0);

The nurse's retention and quality of care may not have significant association with nurse manager's practices.

\section{6) Objectives;}

1.6.1) General objectives;

$>$ To assess the relationship of nurse manager's practices with nurse's retention and quality of care in Public Hospital of Lahore.

1.6.2) Specific objectives;

To assess relationship of nurse manager practices with nurse's retention in Punjab Institute of Cardiology Hospital, Lahore.

$>$ To assess relationship of nurse manager practices with quality of patient care in wards of Punjab Institute of Cardiology Hospital, Lahore.

\section{7) Theoretical Framework for the Study;}

Kouzes and Posners leadership framework and an adaptation of Patient Care Delivery Model developed by(O'Brien - Pallas, Meyer, Hayes, \& Wang, 2011) was used in this study. This is based on the principles of Open Systems Theory. An open system is any entity that takes in assets from its environment, processes them in some way, and produces outputs which then feedbacks to the system as a whole. The feedback loop allows for a system to continually build and adapt. The outputs depend on the inputs and throughputs. Organizations such as hospitals depend on the interactions of the Inputs, throughputs, outputs. An open system such as a hospital is made up of related parts that are connected and when one is improved other parts are affected.

\subsubsection{Conceptual Frame work on patient care delivery Model;}

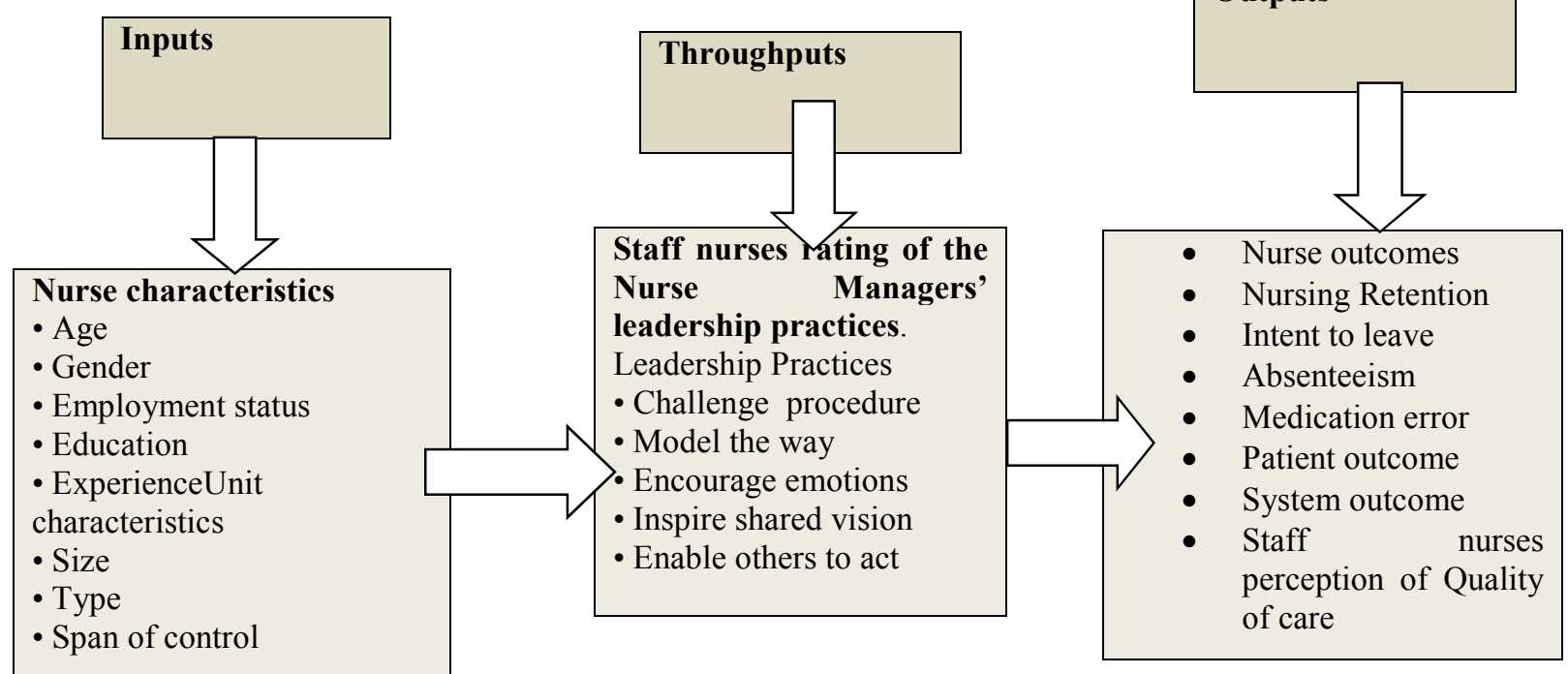

In an open system the interrelationship of the inputs, throughputs and outputs is more important to the functioning of the whole than each part on its own and as an open system there are flexible boundaries. This conceptual framework was chosen because it describes and organizes the complexity of a hospital environment as a system. This study looked at one part of the complex variables within a hospital unit and that is the relationship between nurse managers' leadership practices and specific outputs (Eisler, 2009). 
1.8) Variables;

1.8.1) Independent variable;

Nurse manager's practices

1.8.2) Dependent variables;

$>$ Nurse's Retention

$>$ Quality of care in nursing

\section{9) Conceptual definition;}

Nurse manager practice; "It's about the practices of nurse manager use to change values into activities, ideas into realities, difficulties into innovations, separateness into unity, and risks into rewards"(Kouzes \& Posner, 2001).

$>$ Nursing retention; refers to the ability of an organization to retain its employees (Cascio, 2014).

$>$ Quality of care; Quality of nursing care is defined as care that is provided according to hospitals' criteria and job necessities (Mrayyan, 2006).

\subsection{0) Operational definitions;}

$>$ Nurse manager practice; The five nurse manager practices measured by Leadership Practice Inventory (LPI) developed by (Kouzes \& Posner, 2001), Challenge progress, Motivate shared idea, Qualify others be active, Model way, and Inspire emotions.

$>$ Nursing retention; Nursing retention refers to the ratio of Registered Nurses that leave Hospital in a given year.

$>$ Quality of care; Quality of care reported by staff nurses as measured by two questions:

- Staff nurses' perception of quality of patient care on the wards of hospitals in the last year has proved, stayed the same, or deteriorated.

- Staff nurses' perception of quality of nursing care on their last shift was poor, fair, good or excellent.

1.11) Significance of the study; Significance was discussed under the direction of patients, health care provider, management, policy maker and future researcher. Through this current study finding was help professional nurses in provision of quality of care to the patients. Patients; the result of this study was helped patient's to be treated with more quality of care. Nurses feel satisfied with good nurse manager practices, if they feel satisfied with their profession, absenteeism rate, intent to leave and medication errors will be decreased. In this way they will deliver best nursing care to patients. Health care provider; this study findings will help health care provider think positively and display positivism in their hospital environment in this way, they will begin to feel better about their career. Nurse Manager that can help related to the nurses' retention and promotion of quality of care, it's important to learn how to improve the nurse manager practices and nursing retention and quality of care in hospital setting. Organization; The base of findings of this study, organization will take measures to improve the nurse manager's practices through consulting the lectures, workshop, refresher courses, which impact on nursing retention and quality of care in prestige of organization. After conducting lectures and workshops, she will adopt best strategies which lead staff nurse's retention, quality of care and decrease the absenteeism, intent to leave and medication error in hospital settings. Policy makers; The study finding will help policy makers to improve the nurse manager's practices, retention of staff nurses and quality of care. Further research; The result of this study will give direction to the future researcher to utilize this study as a literature and guidance. Additionally study will help them to identify the study gap. Nursing school will be able to incorporate the results of this study into the leadership curriculums. The hospitals will also benefit from the nurse manager practices and improves retention and quality of care.

\section{Literature Review}

In 2008, unadjusted death, risk factors, and inability to protect rates 3.4, 35.7, and 9.3 percent, individually. Staffing and learning planning of staff nurses were considerably relationship with patient results. Subsequently, modifying of patient, health care facility, patients in health care organization with poor manager practice had significantly increased chances of death (chances proportion, 1.37; 95 percent certainty interval, 1.07-1.76) and inability towards save (chances proportion, 1.48; 95 percent certainty interval, 1.07-2.03) (Friese, Lake, Aiken, Silber, \& Sochalski, 2008). According to Park \& Jones, about 13\% nurses had intent to leave after 1 year, and 37\% detailed that they planned to change professions sooner rather than later. Nursing literature reported that poor practices, shortage of staff nurses such as intent to leave, absenteeism, and anxiety associated with forceful working condition and high patient observation are fundamental causes nurses are leaving their professions in their first year of job (Park \& Jones, 2010). In Belgian, 29.5\% of nurses have an intention-to-leave the hospital. Patient-ton urse staffing ratios and nurse work environments are significantly $(\mathrm{p}<0.05)$ associated with intention-to-leave. Interviews with Chief Nurse Officers revealed that high performing hospitals showing low nurse retention were in contrast to poor management practices and low performing hospitals characterized by flat health care organization 
structure with participative management style, structured education programs and career opportunities for nurses (Van den Heede et al., 2013). All-around record lack of nurses generally is identified with numerous variables which include decreasing enrolments into nurse training programs, low retention rates within the workforce, and promotion of quality of care. Predict a lack of 40,000 nurses in Australia by 2010. In Victoria alone there is a predicted shortfall of 8500 by 2(Karmel \& Li, 2002)011-12 (Department of Human Services, 2004) and a recognized national lack of health professionals in general. In Queensland, nurse loss rates are as high as $40 \%$ in the first 2 years of occupation (C. Duffield et al., 2014). A disturbing 67.5\% described intent to leave inside the next one to three years due to poor management of nurse, many of whom related to leave their job(36.7\%). Inside nurses whom described to leave the health care organization but stay in Lebanon, $22.1 \%$ arrangement to change the alternate wellbeing health organization in Lebanon, $29.4 \%$ plan to leave their job and $48.5 \%$ had additional strategies. Nurses informed being least satisfied with extrinsic rewards (El-Jardali et al., 2009). According to Kramer et.al, clinical staff nurses in 14 Magnet hospitals recognized 8 work methods, associations imperative toward protect and quality of patient care results. These 8 work methods - collegial-collaborative RN-MD-ID associations, practice of clinical independence, working with practically accomplished peers, helpful nursing manager associations, supposed capability of recruitment, manipulate of nursing training, preservation of patientfocused culture, and helpful for training have been recognized as necessary by clinical nurses in 81 extra Magnet and Magnet hopeful hospitals in 34 states and by nurses in 13 home healthcare services officers in 9 states (Kramer, Schmalenberg, \& Maguire, 2010). In 2002, near to 1.3 million enrolled nurses work in health care in the United States, as health care facilities have reacted toward economic stress from Medicare, provide care, and further nonpublic customers, enlisted nurses have become gradually disappointed with the occupied environments in health care organizations. They report that they are contributing less time dealing care with progressively sick patients and assume that wellbeing and quality of care are breaking down. Despite the fact that the amount of hours of care per patient day gave by registered nurses ascended through the mid-1990s, some question whether nurses has enhanced progressively satisfactory to keep pace with the growing seriousness of illness among hospitalized patients and hence to ensure secure and promotion of quality of care (Needleman, Buerhaus, Mattke, Stewart, \& Zelevinsky, 2015). Study was conducted in 2008, 56 percent nurses recorded high rates of burnout, $60 \%$ were disappointed of their profession, and 59\% ordered quality care of patients in organization as poor. Approximately $33 \%$ had less than 4 years of their job experience, and greater than $66 \%$ had lesser than 10 . Only $50 \%$ nurses reported that there were sufficient RNs to give quality care and greater part stated that collaboration among staff nurses and doctors were inadequate. Chances of high burnout of nurses, absenteeism purpose to leave their job and poor quality patient care were twice as high in health care services with $50 \%$ untrained nurses than with $20 \%$ untrained nurses, and 40\% higher in health care services where nurses had less suitable relationships with doctors. Insufficient nursing staff in hospitals were $50 \%$ burnout, twice as possible to be disappointed, and $75 \%$ more likely to report poor or fair quality care than nurses in improved staffed hospitals (Ross, 2017). It has been documented that in British hospitals where nurses are overworked and underpaid, the sickness absenteeism apparently costs the government billions of pounds. The British hospitals are additionally challenged with poor patient and nurse ratio, staffing levels which are often worsened by a high rate of absenteeism among staff nurses. Their nurses are working under continuous threats of public violence and criticism. The South African health institutions are also faced with similar challenges of poor working conditions of nurse manager which contribute to low nurse retention and increased absenteeism. Physical exhaustion from workload also leads to absenteeism. Valkenberg Hospital staff members are also facing criticisms from patients' family members that they care for(Kovane, 2015). In Georgia and Colorado, in 36 organizations, $19 \%$ in measurements $(605 / 3216)$ were error in medications. The greatest regular errors by grouping were not right time (43\%), oversight (30\%), incorrect measurement (17\%), and unapproved medications (4\%). 7\% errors were refereed probable antagonistic medication measurements. Medications error rates in the 3 settings were no significant difference $(P=.82)$ or by size $(P=.39)$. In Georgia $(P=.04)$ medications errors rates were high than Colorado (Barker, Flynn, Pepper, Bates, \& Mikeal, 2002). In a study in United States, $42 \%$ of the nurses mentioned that there was no factor causing their error while $23.6 \%$ referred to carelessness and distraction of nurses, and $11.3 \%$ referred to low retention of nurses as the factors causing medication errors (Ehsani et al., 2013). Another study was conducted in England reported a medication error rate of about $15 \%$ and nurses were responsible for $56 \%$ of these errors. (Alsulami, Conroy, \& Choonara, 2013) In United States and Europe Health Care organizations, the level of nurse reporting poor quality care various significantly by nation (from $11 \%$ (Ireland) to $47 \%$ (Greece), rates of nurses who provide poor care grade in hospitals (4\% (Switzerland) to $18 \%$ (Poland). We found out a huge range of nurse burnout (10\% (Netherlands) to $78 \%$ (Greece), their profession frustration (11\% (Netherland) to $56 \%$ (Greece)), and purpose to leave (14\% (US) to $49 \%$ (Finland, Greece)). Patient also varied considerably high ratings of their hospitals (35\% (Span) to $61 \%$ (Finland, Ireland), and patients amounts of willing to mention their hospital (53\% (Greece) to $78 \%$ (Switzerland)(Aiken et al., 2012). 
Methodology

3.1) Study design;

A quantitative descriptive cross sectional study was conducted.

\section{2) Study setting;}

Data was collected from nurses at Nursing Counter or Resting Bay of Punjab Institute of Cardiology Lahore. This is located at jail road Lahore.

\section{4) Study Population;}

Data was collected from Registered Nurses of Punjab Institute of Cardiology Hospital of Lahore. There are 450 registered nurses working in Punjab Institute of Cardiology.

\section{5) Study Duration;}

This study approximately was taken in 4-5 months (January,2018 to May, 2018).

\section{6) Sample Size;}

Sample size calculate according to Slovin's formula (Slovin, 1960).

$\mathrm{N}=\mathrm{N} / 1+\mathrm{N}(\mathrm{e})^{2}$

$\mathrm{n}=$ Sample size

$\mathrm{N}=$ Population size

$\mathrm{e}^{2}=$ margin of error $(0.05)$

$\mathrm{n}=450 / 1+450(0.05)^{2}$

$\mathrm{n}=450 / 1+450(0.0025)=450 / 1+1.125$

$\mathrm{n}=450 / 2.125=211$

\section{7) Sampling technique;}

Data was collected from convenient sampling technique.

\section{8) Inclusion criteria;}

Both ( Male and Female) Staff Nurses of Punjab Institute of Cardiology Lahore was included who have age 20 45 year, who have experience at least 2 year, and willing for participation.

\section{9) Exclusion Criteria;}

Both ( Male and Female) Staff Nurses of Punjab Institute of Cardiology Lahore was excluded who are not willing to participate in study and have age less than 20 year and above than 45 year and who have experience less than 2 year.

\subsection{0) Data Collection method;}

Data was collected by using a predesigned questionnaire, and questionnaire was filled by Registered Nurses.

\subsection{1) Data Collection Tool:}

In this study well structured questionnaire was used with closed ended questions as per likert scale, which is adopted from previous study "The leadership practices of Nurse Managers and the association with nursing staff retention and the promotion of quality care in hospital". The questionnaires consist of three sections. First section consist of demographic information of participants. Second section consist of nurse manager's practices with five point of likert scale $(\mathbf{1}=$ Almost Never $\mathbf{2}=$ Rarely $\quad \mathbf{3}=$ Seldom $\quad \mathbf{4}=$ Very Frequently $\quad \mathbf{5}=$ Almost Always). Third section consists of Nurse's retention and quality of care.

\subsection{2) Data Analysis method;}

After collection the data, it was analyzed on SPSS version 21.Mean, median, and mode will be computed for data will be displayed in tables, charts, and graphs.

\subsection{3) Ethical considerations;}

Ethical principle must be considered during research study. Written permission was take from the Ethical Review Board of University of Lahore (UOL). Permission was gotten for data collection from Deputy Nursing Superintendent of Punjab Institute of cardiology Lahore. Confidentially maintained only by a code number on the questionnaire. Participants will be informed about the purpose of study, which is only for Academic. It is a data base studies no harm for participants. 


\section{RESULTS}

\section{Data Analysis and interpretations}

Data analysis and interpretation means to define characteristics of each component in various aspects and measure it mathematically by applying different strategies or test, manipulate the required things by following the statistics rules or principles to determine the relationship between components or variables and that relation is to interpret and examine the finding with aspects (Thompson, 1993).

\section{Demographic Data Analysis}

Table 1 Demographic information of participants Statistics

\begin{tabular}{|c|c|c|c|c|}
\hline S. no & Demographic information & Statements & Frequency & Percentage \\
\hline \multirow[t]{2}{*}{1} & \multirow[t]{2}{*}{ Sex } & Female & 171 & $19 \%$ \\
\hline & & Male & 40 & $81 \%$ \\
\hline \multirow[t]{5}{*}{2} & \multirow[t]{5}{*}{ Age group } & 20year-25year & 62 & $29.4 \%$ \\
\hline & & 26year-30year & 64 & $30.3 \%$ \\
\hline & & 31year-35year & 40 & $19.0 \%$ \\
\hline & & 36year-40year & 30 & $14.2 \%$ \\
\hline & & 41year-45year & 15 & $7.1 \%$ \\
\hline \multirow[t]{2}{*}{3} & \multirow[t]{2}{*}{ Marital status } & Single & 87 & $41 \%$ \\
\hline & & Married & 124 & $59 \%$ \\
\hline \multirow[t]{4}{*}{4} & \multirow[t]{4}{*}{ Qualification } & Diploma in General Nursing \& Midwifery & 79 & $37 \%$ \\
\hline & & Specialization & 68 & $32 \%$ \\
\hline & & BSN (4year program)/ Post RN BSN & 58 & $28 \%$ \\
\hline & & MSN & 6 & $3 \%$ \\
\hline \multirow[t]{5}{*}{5} & \multirow[t]{5}{*}{ Job Experience } & 2year-6year & 85 & $40.3 \%$ \\
\hline & & 7year-11year & 49 & $23.2 \%$ \\
\hline & & 12year-16year & 37 & $17.5 \%$ \\
\hline & & 17year-21year & 26 & $12.3 \%$ \\
\hline & & 22year-26year & 14 & $6.6 \%$ \\
\hline \multirow[t]{2}{*}{6} & \multirow{2}{*}{$\begin{array}{l}\text { My immediate } \\
\text { supervisor is: }\end{array}$} & A Registered Nurse & 72 & $34.1 \%$ \\
\hline & & A Head Nurse & 139 & $65.9 \%$ \\
\hline \multirow[t]{4}{*}{7} & \multirow[t]{4}{*}{ Working your current unit: } & Emergency Department & 82 & $38.9 \%$ \\
\hline & & $\mathrm{ICU}$ & 32 & $15.2 \%$ \\
\hline & & Wards & 70 & $33.2 \%$ \\
\hline & & $\mathrm{OT}$ & 27 & $12.8 \%$ \\
\hline 8 & Total & & 211 & $100 \%$ \\
\hline
\end{tabular}

\section{Demographic Variables Analysis}

\section{Table- 1}

\section{Descriptive statistics with respect to Age:}

\begin{tabular}{|l|r|}
\hline \multicolumn{2}{|c|}{ Age } \\
\hline Mean & 28.00 \\
\hline Std. Deviation & 2.81 \\
\hline Minimum & 21 \\
\hline Maximum & 40 \\
\hline
\end{tabular}


Figure- 1

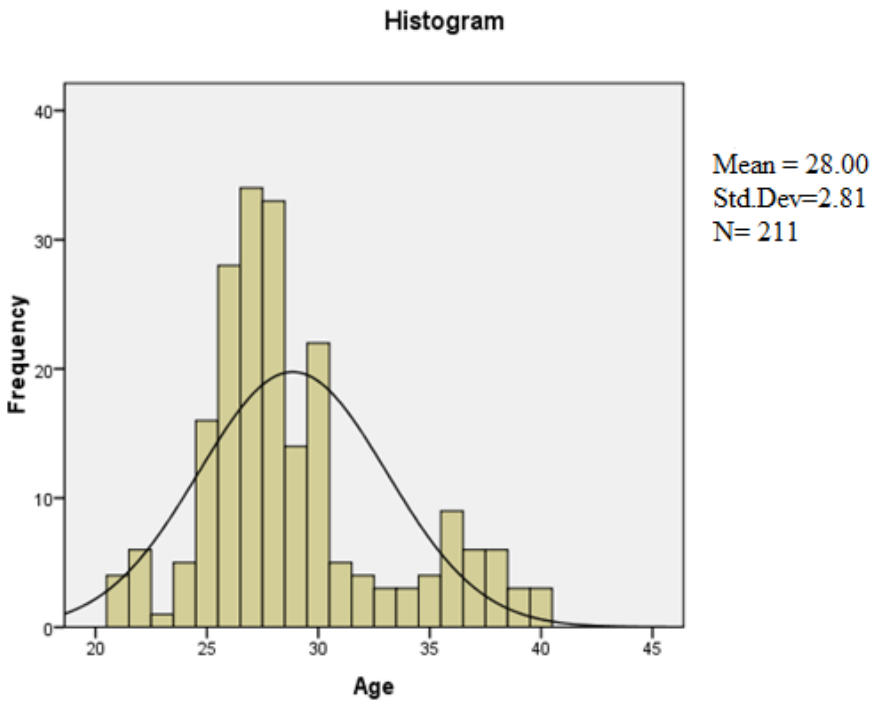

Figure 1 showed analyze the number of participants according to their age, the mean age of participants were $28.00 \pm 2.81$, the maximum age was 40 years old as compare with minimum age was 21 years old.

Table \# 2

Descriptive statistics with respect to Grouped Age:

\begin{tabular}{|c|c|c|}
\hline Grouped Age & Frequency & Percent \\
\hline $20-25$ & 62 & 29.4 \\
\hline $26-30$ & 64 & 30.3 \\
\hline $31-35$ & 40 & 19.0 \\
\hline $36-40$ & 30 & 14.2 \\
\hline $41-45$ & 15 & 7.1 \\
\hline Total & 211 & 100.0 \\
\hline
\end{tabular}

Figure- 2

Grouped Age of Participants

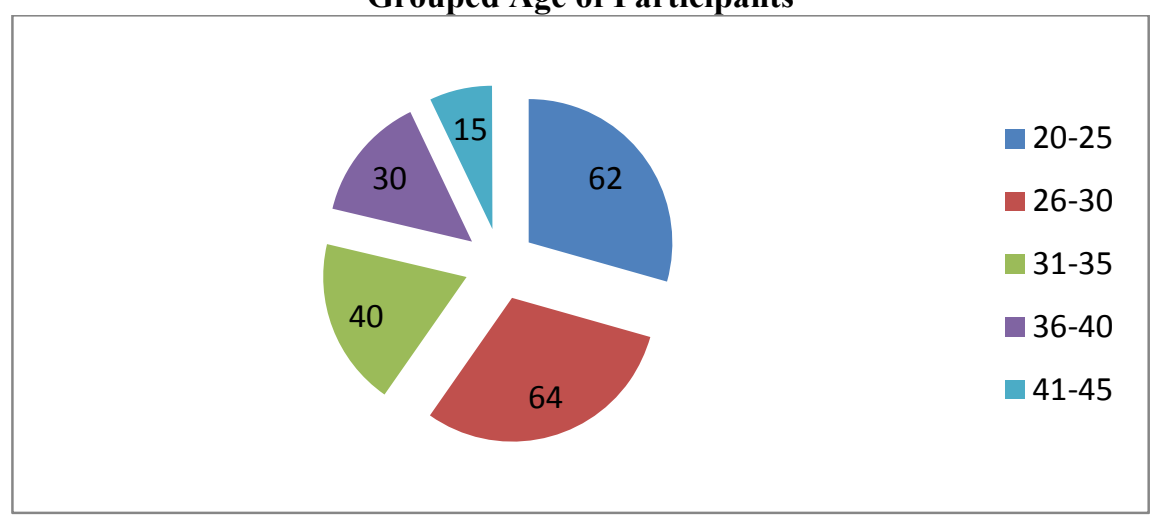

Table 2 showed analyze the number of participants according to their age it was noted that $64(30.3 \%)$ out of 211 charge nurses were having age in range of 26-30years, whereas, 62(29.4\%) were having 20-25 years old and $40(19 \%)$ were $31-35$ years while $30(14.2 \%)$ having age group between $36-40$ years and only $15(7.1 \%)$ having age 41-45 years. 
Table \# 3

Frequency distribution with respect to Gender

\begin{tabular}{|c|c|c|}
\hline Gender & Frequency & Percent \\
\hline Male & 40 & $19 \%$ \\
\hline Female & 171 & $81 \%$ \\
\hline Total & 211 & $100 \%$ \\
\hline
\end{tabular}

Figure- 3

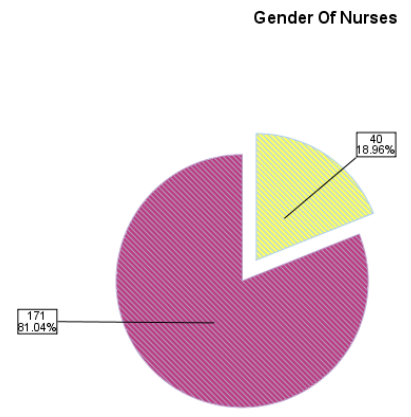

Table 3 showed that only 40(19\%) were male as compare with female 171(81.\%)

\section{Table \# 4}

Frequency distribution with respect to Marital Status:

\begin{tabular}{|c|c|c|}
\hline Marital Status & Frequency & Percent \\
\hline Single & 87 & 41 \\
\hline Married & 124 & 59 \\
\hline Total & 211 & 100.0 \\
\hline
\end{tabular}

Figure- 4

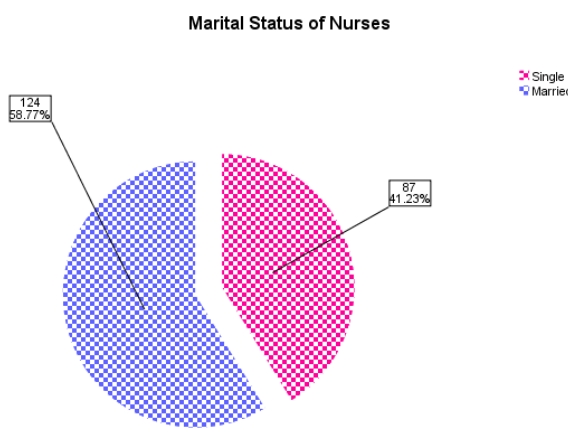

Table 4 showed analyze the number of participants according to their marital status, it was noted that $124(59 \%)$ out of 211 charge nurses were married and $87(41 \%)$ were unmarried.. 


\section{Table \# 5}

Frequency Distribution with respect to Professional Qualification:

\begin{tabular}{|l|l|l|}
\hline Professional Qualification & Frequency & Percent \\
\hline Diploma in General Nursing \& Midwifery & 79 & $37 \%$ \\
\hline Specialization & 68 & $32 \%$ \\
\hline Post RN/BSCN & 58 & $28 \%$ \\
\hline MSN & 6 & $3 \%$ \\
\hline Total & 211 & $100 \%$ \\
\hline
\end{tabular}

Figure- 5

Qualification of Nurses

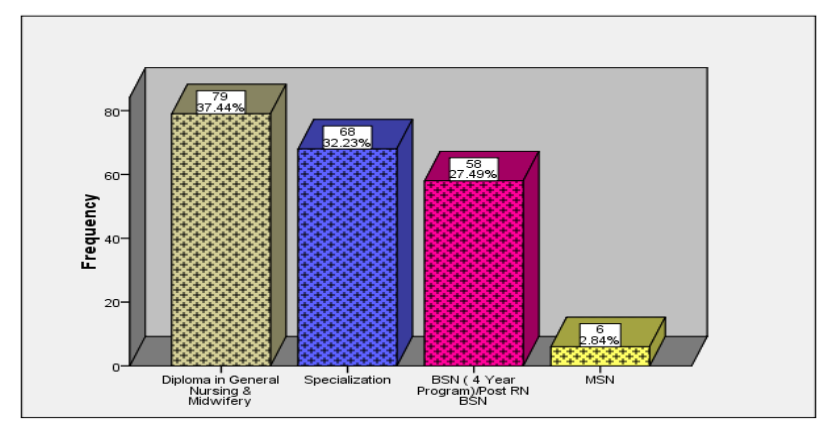

Table 5 showed the working experience it was noted that 79(37.4\%) charge nurses were having Diploma of nursing , 68(32\%) having professional education of specialization level while $58(28 \%)$ staff nurses having higher education like Post RN/BSCN and MSN 6(3\%).

Table \# 6

Status of Working Experience:

\begin{tabular}{|l|l|l|}
\hline Working Experience & Frequency & Percent \\
\hline $2-6$ Years & 85 & $40.3 \%$ \\
\hline $7-11$ Years & 49 & $23.2 \%$ \\
\hline $12-16$ Years & 37 & $17.5 \%$ \\
\hline $17-21$ Years & 26 & $12.3 \%$ \\
\hline $22-26$ Years & 14 & $6.6 \%$ \\
\hline Total & 211 & $100 \%$ \\
\hline
\end{tabular}

Table 6 showed working experience it was noted that $85(40.3 \%)$ out of 211 charge nurses were having working experience in range of 2-6 years, whereas, 49(23.2\%) having experience of 7-11 years, 37(17.5\%) having 12-16 year experience, 26(12.3\%) nurses 17-21 years while only 14(6.6\%) having experience of 22-26 years.

Figure- 6

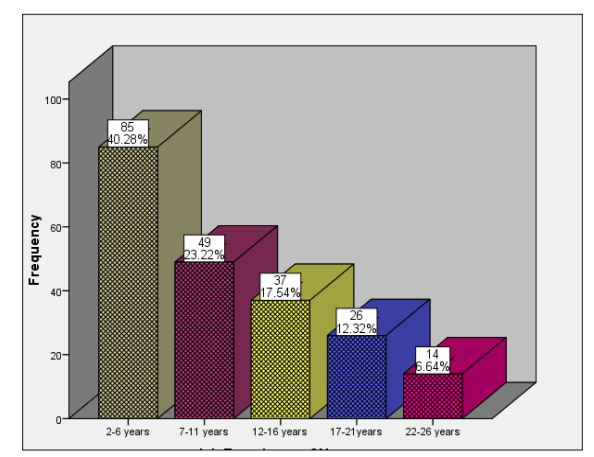


Table \# 7

My Immediate Supervisor

\begin{tabular}{|l|l|l|}
\hline My Immediate Supervisor & Frequency & Percent \\
\hline A Registered Nurse & 72 & $34.1 \%$ \\
\hline A Head Nurse & 139 & $65.9 \%$ \\
\hline Total & 211 & $100 \%$ \\
\hline
\end{tabular}

Figure- 7

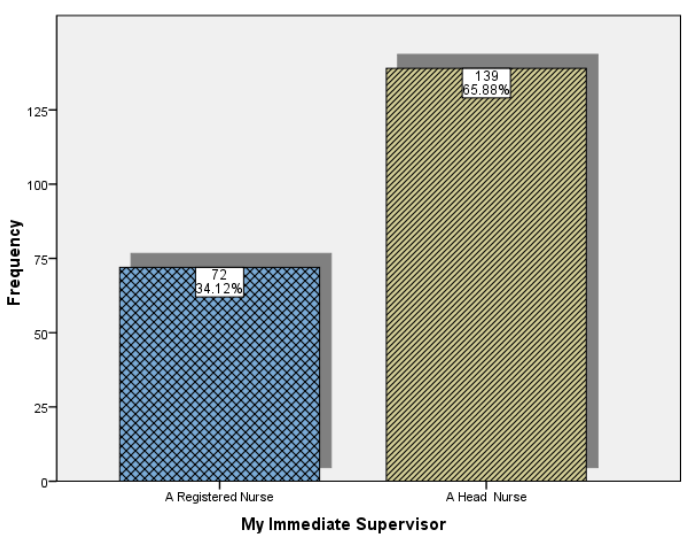

Table 7 showed that $72(34.12 \%)$ registered nurses and $139(65.88 \%)$ out of 211 head nurses were working as a supervisor.

Table \# 8

Specialty area of current unit

\begin{tabular}{|l|l|l|}
\hline Current Unit & Frequency & Percent \\
\hline Emergency Ward & 82 & $38.9 \%$ \\
\hline ICU & 32 & $15.2 \%$ \\
\hline Wards & 70 & $33.2 \%$ \\
\hline OT & 27 & $12.8 \%$ \\
\hline Total & 211 & $100 \%$ \\
\hline
\end{tabular}

Figure- 8

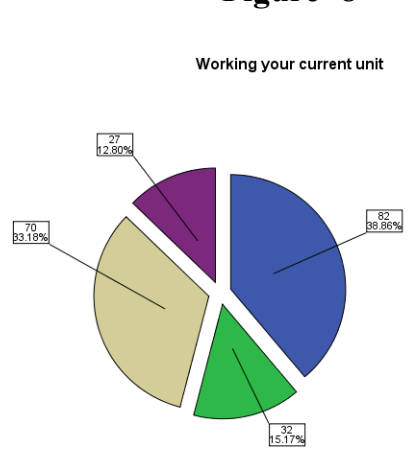

Table 8 showed that 83(38.9\%) nurses working at Emergency Ward, 32((15.2\%) working in ICU ward, 70(33.2\%) performing their duties in wards and $27(12.8 \%)$ working in OT. 
Table- 9

Test of Normality for research variable

\begin{tabular}{|l|l|l|l|l|}
\hline \multirow{2}{*}{ Variable } & \multicolumn{3}{|l|}{ Shapiro-Wilk } & \multicolumn{3}{l|}{ Sig. } \\
\cline { 2 - 4 } & Statistic & df & 0.912 & \\
\hline Practices of Nursing Manager & 0.883 & 211 & Normally \\
\hline Factor Nursing retention & 0.911 & 211 & 0.793 \\
\hline Quality of care & 0.810 & 211 & 0.962 & Distributed Data \\
\hline
\end{tabular}

Table 9 To determine the data is normally distributed or not, used test of Normality. The data showed that Practices of Nursing Manager, Factor of Nursing retention and quality of care are normally distributed.

Table- 10: Frequency Distribution with respect to Practices of Leadership (Q1-15)

\begin{tabular}{|c|c|c|c|c|c|c|}
\hline S.No & Practices of Leadership & $\begin{array}{l}\text { Almost } \\
\text { Never }\end{array}$ & Rarely & Seldom & $\begin{array}{l}\text { Very } \\
\text { Frequently }\end{array}$ & $\begin{array}{l}\text { Almost } \\
\text { Always }\end{array}$ \\
\hline 1. & $\begin{array}{l}\text { My manager seeks out challenging opportunities } \\
\text { that test his/her own skills and abilities. }\end{array}$ & 55 & 26 & 42 & 54 & 34 \\
\hline 2. & $\begin{array}{l}\text { My manager talks about future trends that will } \\
\text { influence how our work gets done. }\end{array}$ & 74 & 41 & 59 & 28 & 19 \\
\hline 3. & $\begin{array}{l}\text { My manager develops cooperative relationships } \\
\text { among the people he/she works with. }\end{array}$ & 65 & 31 & 34 & 39 & 42 \\
\hline 4. & $\begin{array}{l}\text { My manager sets a personal example of what } \\
\text { he/she expects from others. }\end{array}$ & 53 & 42 & 40 & 40 & 36 \\
\hline 5. & My manager praises people for a job well done. & 55 & 45 & 26 & 42 & 43 \\
\hline 6. & $\begin{array}{l}\text { My manager challenges people to try out new and } \\
\text { innovative approaches to their work. }\end{array}$ & 59 & 46 & 31 & 45 & 30 \\
\hline 7. & $\begin{array}{l}\text { My manager describes a compelling image of } \\
\text { what our future could be like. }\end{array}$ & 42 & 36 & 40 & 41 & 52 \\
\hline 8. & $\begin{array}{l}\text { My manager actively listens to diverse points of } \\
\text { view. }\end{array}$ & 0 & 42 & 84 & 84 & 0 \\
\hline 9. & $\begin{array}{l}\text { My manager spends time and energy on making } \\
\text { certain that the people he/she works with adhere } \\
\text { to the principles and standards that have been } \\
\text { agreed on. }\end{array}$ & 42 & 0 & 42 & 43 & 84 \\
\hline 10. & $\begin{array}{l}\text { My manager makes it a point to let people know } \\
\text { about his/her confidence in their abilities. }\end{array}$ & 0 & 42 & 84 & 42 & 43 \\
\hline 11. & $\begin{array}{l}\text { My manager searches outside the formal } \\
\text { boundaries of our organization for innovative } \\
\text { ways to improve what we do. }\end{array}$ & 85 & 42 & 0 & 84 & 0 \\
\hline 12. & $\begin{array}{l}\text { My manager appeals to others to share an exciting } \\
\text { dream of the future. }\end{array}$ & 0 & 43 & 0 & 84 & 84 \\
\hline 13. & $\begin{array}{l}\text { My manager treats others with dignity and } \\
\text { respect. }\end{array}$ & 0 & 0 & 211 & 0 & 0 \\
\hline 14. & $\begin{array}{l}\text { My manager follows through on the promises and } \\
\text { commitments that he/she makes. }\end{array}$ & 0 & 42 & 0 & 169 & 0 \\
\hline 15. & $\begin{array}{l}\text { My manager makes sure that people are creatively } \\
\text { rewarded for their contributions to the success of } \\
\text { our projects. }\end{array}$ & 0 & 0 & 0 & 84 & 127 \\
\hline
\end{tabular}

Table 10 showed the factors of practice of nursing manage, it was observed that 55(26.01\%) almost never that manager seeks out challenging opportunities that test his/her own skills and abilities , 74(35.07\%) manager talks about future trends that will influence how our work gets done almost never ,65(30.8\%) manager develops cooperative relationships among the people he/she works almost never , 53(25.1\%) .almost never manager sets a 
personal example of what he/she expects from others, 59(28\%) manager challenges people to try out new and innovative approaches to their work, 52(25\%) almost always manager describes a compelling image of what our future could be like, 84(40\%). Seldom and very frequently manager actively listens to diverse points of view, $84(40 \%)$ almost always manager spends time and energy on making certain that the people he/she works with adhere to the principles and standards that have been agreed on., 84(40\%) seldom manager makes it a point to let people know about his/her confidence in their abilities, $.84(40 \%)$ almost frequently manager searches outside the formal boundaries of our organization for innovative ways to improve what we do, 84(40\%). Very frequent and almost always manager appeals to others to share an exciting dream of the future, $211(100 \%)$ manager seldom treats others with dignity and respect, $169(81 \%)$ very frequently manager follows through on the promises and commitments that he/she makes., 127(60\%) almost always manager makes sure that people are creatively rewarded for their contributions to the success of our projects.

Figure- 9 Practices of Leadership (Q1 - Q8)

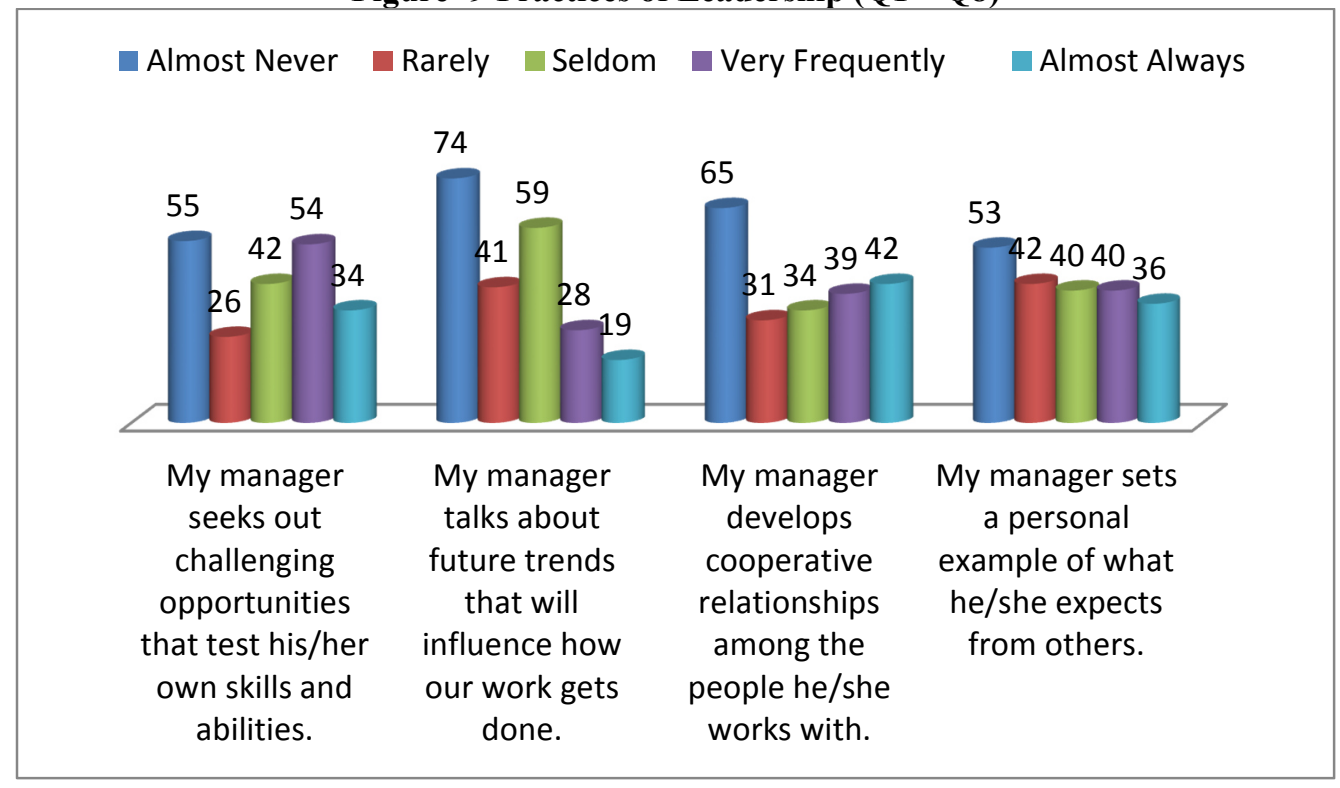

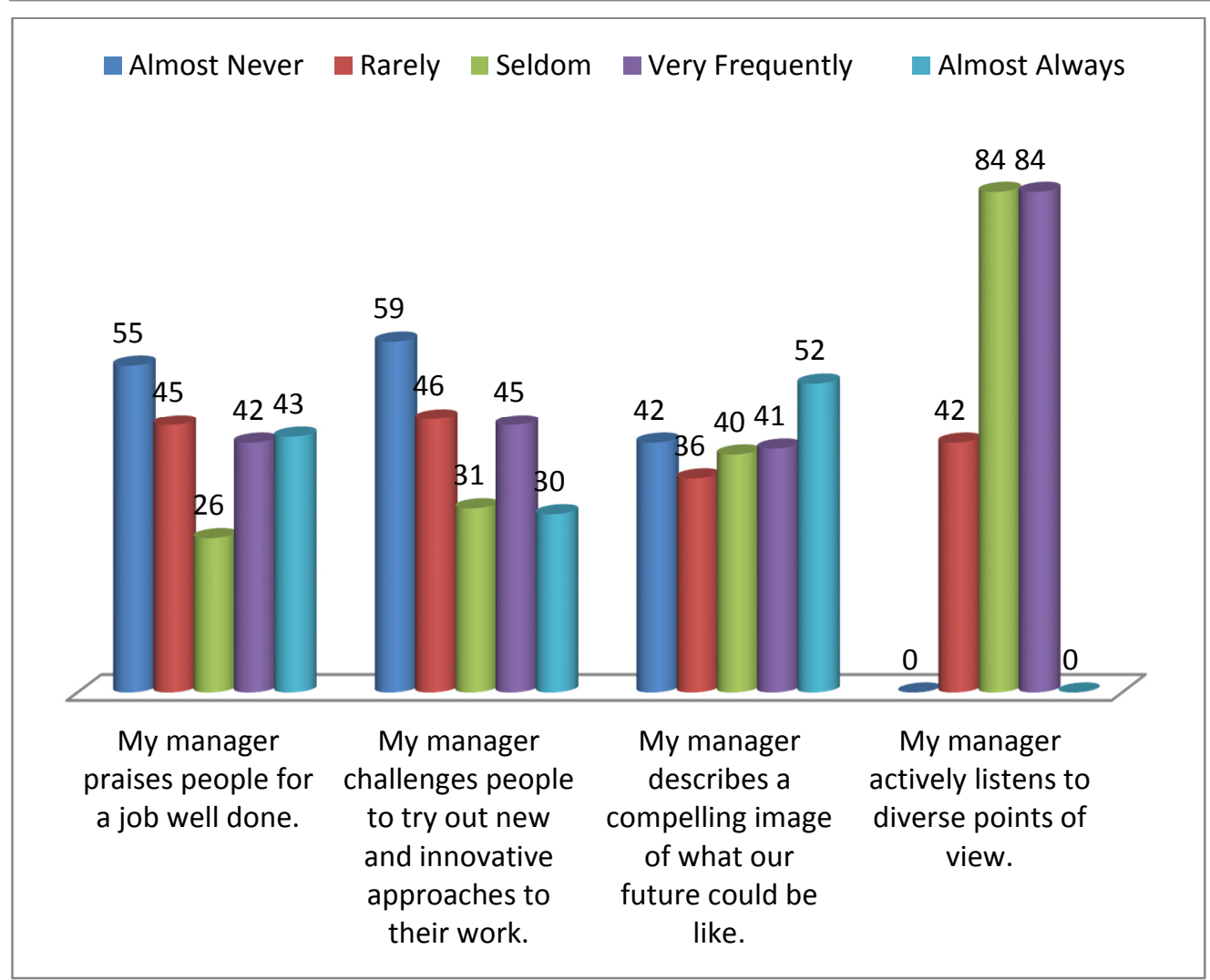


Figure- 10

Practices of Leadership (Q9 - Q15)

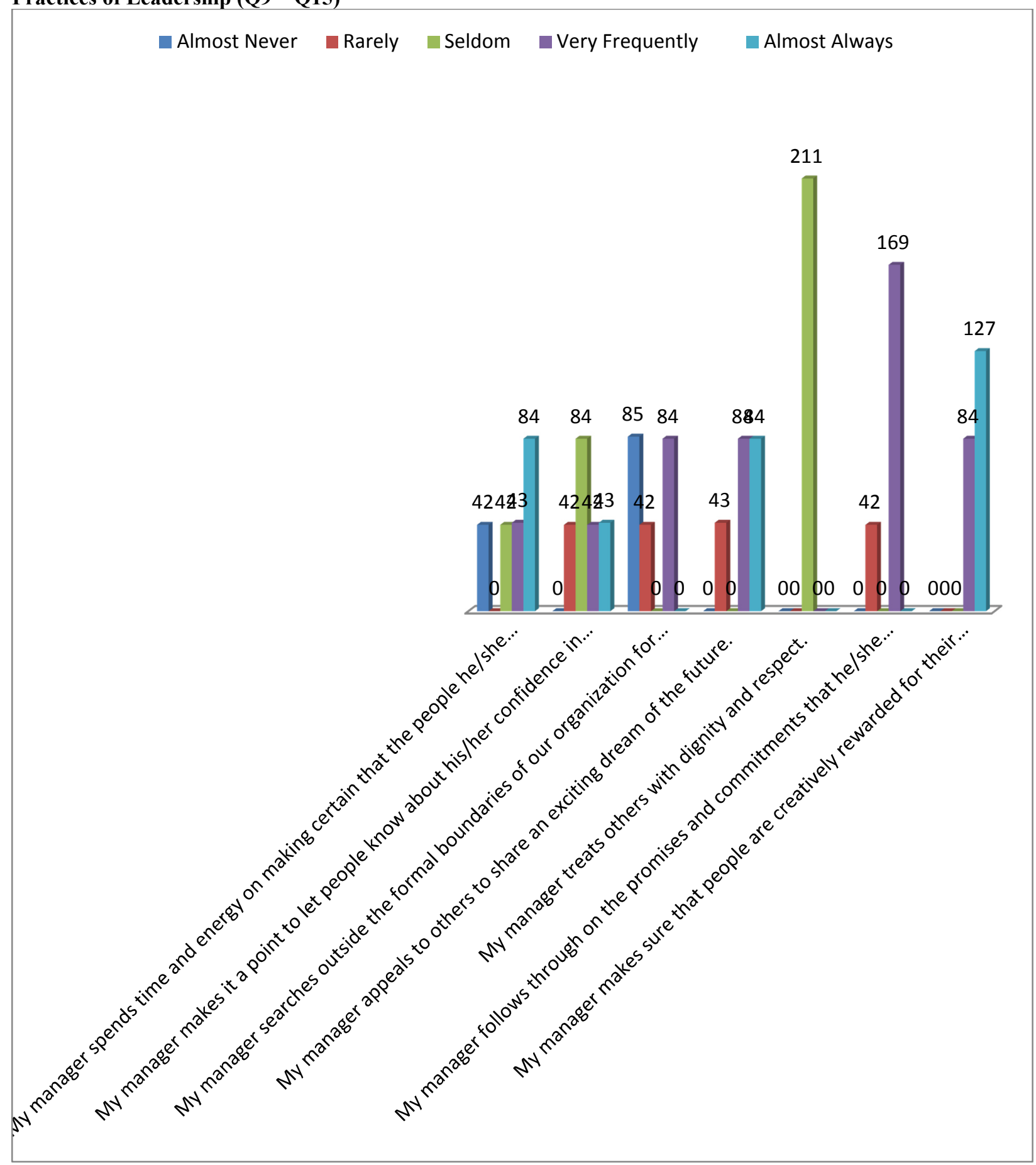


Table No 11

Frequency Distribution with respect to Practices of Leadership (Q15-30)

\begin{tabular}{|c|c|c|c|c|c|c|}
\hline S.No & Practices of Leadership & $\begin{array}{l}\text { Almost } \\
\text { Never }\end{array}$ & Rarely & Seldom & $\begin{array}{l}\text { Very } \\
\text { Frequently }\end{array}$ & $\begin{array}{l}\text { Almost } \\
\text { Always }\end{array}$ \\
\hline 16. & $\begin{array}{l}\text { My manager asks "What can we learn?" when things } \\
\text { do not go as expected. }\end{array}$ & 43 & 0 & 84 & 84 & 0 \\
\hline 17. & $\begin{array}{l}\text { My manager shows others how their long-term interests } \\
\text { can be realized by enlisting in a common vision. }\end{array}$ & 43 & 0 & 84 & 42 & 42 \\
\hline 18. & $\begin{array}{l}\text { My manager supports the decisions that people make } \\
\text { on their own. }\end{array}$ & 42 & 0 & 85 & 42 & 42 \\
\hline 19. & $\begin{array}{l}\text { My manager is clear about his/her philosophy of } \\
\text { leadership. }\end{array}$ & 0 & 42 & 84 & 85 & 0 \\
\hline 20. & $\mid \begin{array}{l}\text { My manager publicly recognizes people who } \\
\text { exemplify commitment to shared values. }\end{array}$ & 0 & 42 & 0 & 84 & 85 \\
\hline 21. & $\begin{array}{l}\text { My manager experiments and takes risks even when } \\
\text { there is a chance of failure. }\end{array}$ & 45 & 49 & 45 & 42 & 30 \\
\hline 22 & $\begin{array}{l}\text { My manager is contagiously enthusiastic and positive } \\
\text { about future possibilities. }\end{array}$ & 55 & 39 & 33 & 40 & 44 \\
\hline 23. & $\begin{array}{l}\text { My manager gives people a great deal of freedom and } \\
\text { choice in deciding how to do their work. }\end{array}$ & 53 & 38 & 37 & 36 & 47 \\
\hline 24. & $\begin{array}{l}\text { My manager makes certain that we set achievable } \\
\text { goals, make concrete plans, and establish measurable } \\
\text { milestones for the projects and programs that we work } \\
\text { on. }\end{array}$ & 49 & 34 & 37 & 49 & 42 \\
\hline 25. & My manager finds ways to celebrate accomplishments. & 49 & 45 & 37 & 35 & 45 \\
\hline 26. & $\begin{array}{l}\text { My manager takes the initiative to overcome obstacles } \\
\text { even when outcomes are uncertain. }\end{array}$ & 39 & 38 & 57 & 41 & 36 \\
\hline 27. & $\begin{array}{l}\text { My manager speaks with genuine conviction about the } \\
\text { higher meaning and purpose of our work. }\end{array}$ & 64 & 38 & 37 & 36 & 36 \\
\hline 28. & $\begin{array}{l}\text { My manager ensures that people grow in their jobs by } \\
\text { learning new skills and developing themselves. }\end{array}$ & 56 & 37 & 47 & 36 & 35 \\
\hline 29. & $\begin{array}{l}\text { My manager makes progress toward goals one step at a } \\
\text { time. }\end{array}$ & 46 & 25 & 47 & 57 & 36 \\
\hline 30. & $\begin{array}{l}\text { My manager gives the members of the team lots of } \\
\text { appreciation and support for their contributions. }\end{array}$ & 44 & 26 & 28 & 56 & 57 \\
\hline
\end{tabular}

Table 11 showed that $84(40 \%)$ seldom and very frequently, manager asks "What can we learn?" when things do not go as expected, $84(40 \%)$ seldom manager shows others how their long-term interests can be realized by enlisting in a common vision, 85(40\%) manager supports the decisions that people make on their own seldom, $85(40 \%)$ very frequently manager is clear about his/her philosophy of leadership, $85(40 \%)$ almost always manager publicly recognizes people who exemplify commitment to shared values, 49(23\%) rarely manager experiments and takes risks even when there is a chance of failure, 55(26\%) almost never manager is contagiously enthusiastic and positive about future possibilities, almost never 53(25\%) manager gives people a great deal of freedom and choice in deciding how to do their work, very frequent manager makes certain that we set achievable goals, make concrete plans, and establish measurable milestones for the projects and programs that we work on. $49(23 \%)$ manager finds ways to celebrate accomplishments, 57(27\%) almost never manager takes the initiative to overcome obstacles even when outcomes are uncertain., 64(30\%) almost never manager speaks with genuine conviction about the higher meaning and purpose of our work, 56(27\%) manager ensures that people grow in their jobs by learning new skills and developing themselves, 57(27\%) very frequently manager makes progress toward goals one step at a time, $57(27 \%)$ almost always manager gives the members of the team lots of appreciation and support for their contributions. 
Figure- 11

Practices of Leadership (Q16 - Q21)

Almost Never $\square$ Rarely $\square$ Seldom $\square$ Very Frequently $\square$ Almost Always
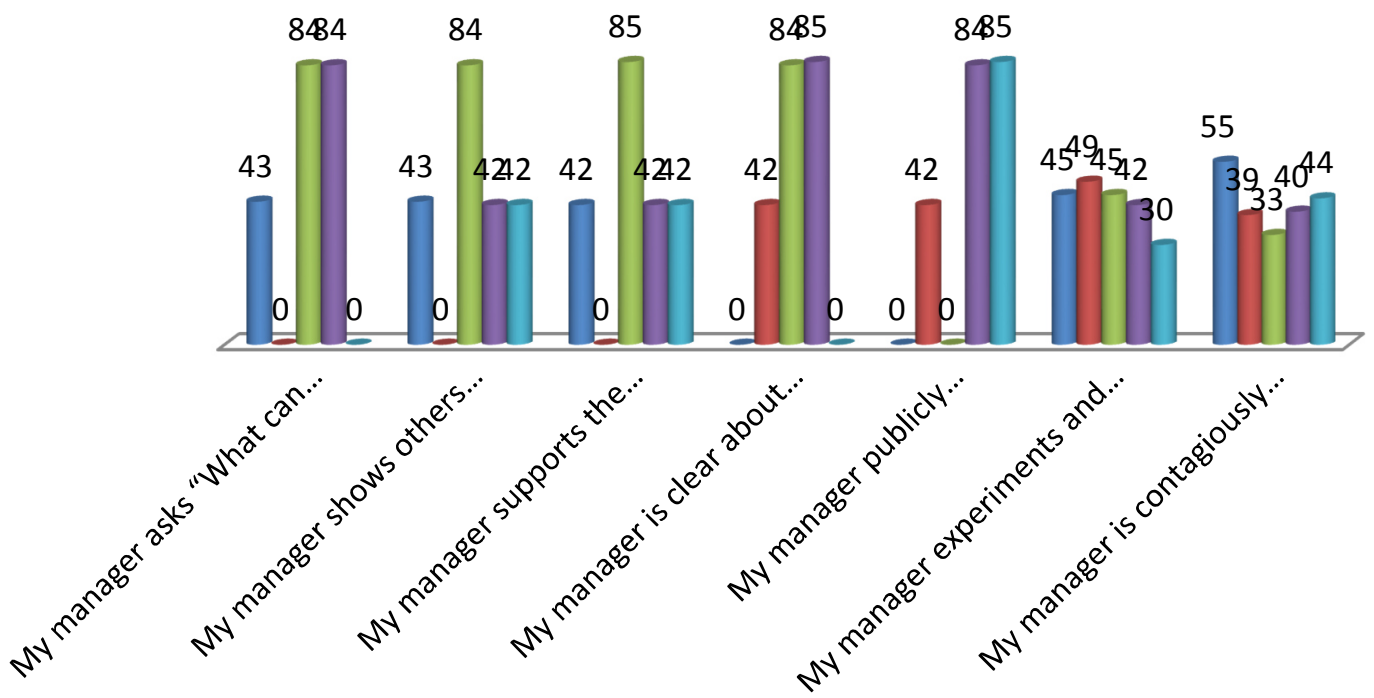

Figure- 12

Practices of Leadership (Q21 - Q25)

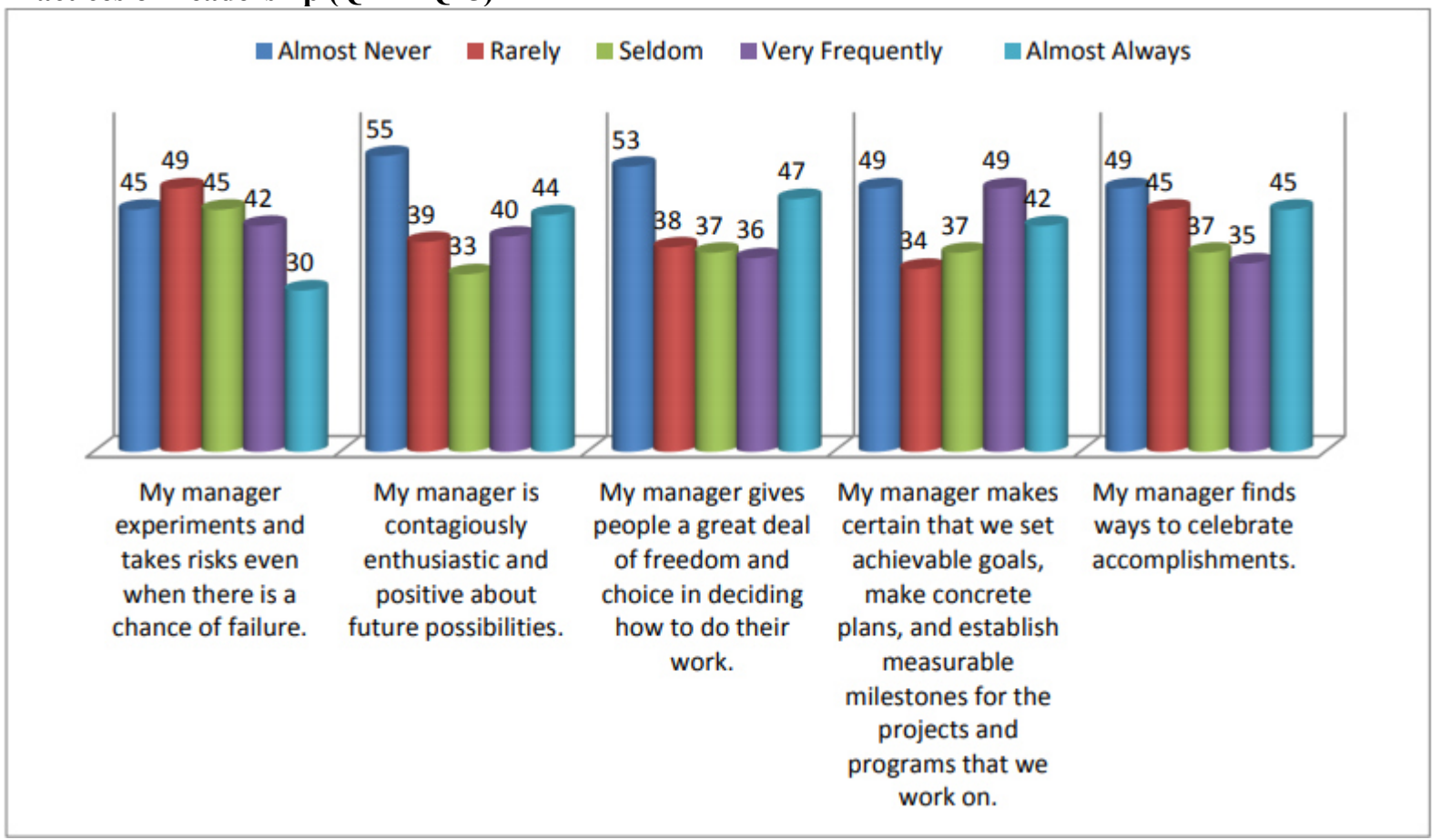


Figure- 13

Practices of Leadership (Q26 - Q30)

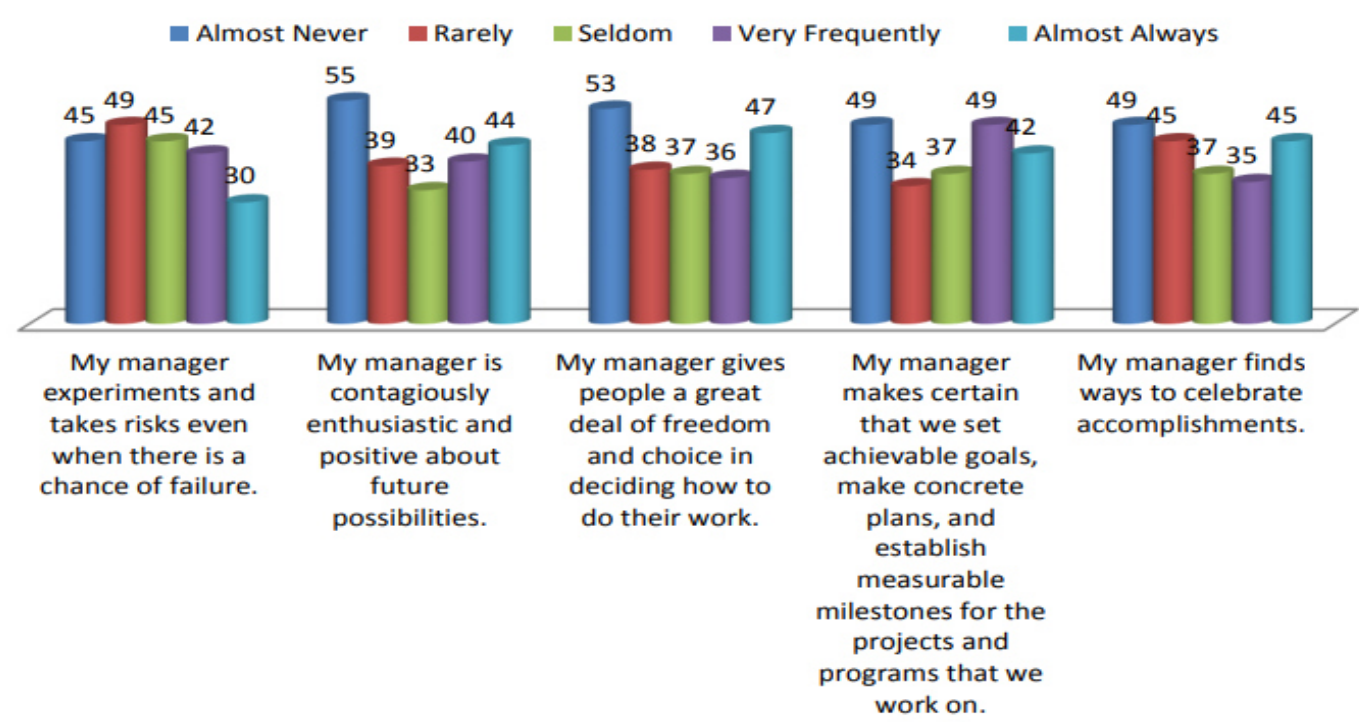

Table-12

Frequency Distribution with respect to Nursing Retention

\begin{tabular}{|c|c|c|}
\hline S. No & \multicolumn{2}{|c|}{ Nursing Retention } \\
\hline \multirow[t]{5}{*}{31.} & \multicolumn{2}{|c|}{ Intending to leave their job or career in the next six months. } \\
\hline & No to both & 57 \\
\hline & Yes to job, no to career & 53 \\
\hline & Yes to career, no to job & 49 \\
\hline & Yes to both & 42 \\
\hline \multirow[t]{6}{*}{32.} & \multicolumn{2}{|c|}{ Absence from work in the last six months. } \\
\hline & 1. None & 49 \\
\hline & 2. 1-2 days & 37 \\
\hline & 3. 1-2 days & 53 \\
\hline & 4. 4-5 days & 26 \\
\hline & 5. More than 5 day & 46 \\
\hline
\end{tabular}

Table 12 showed that factors of nursing retention, 57(27\%) said no to both when asked about Intending to leave their job or career in the next six months , 53(23\%) absence from work in the last six months.

Figure- 14 Nursing Retention

Intending to leave their job or career in the next six months

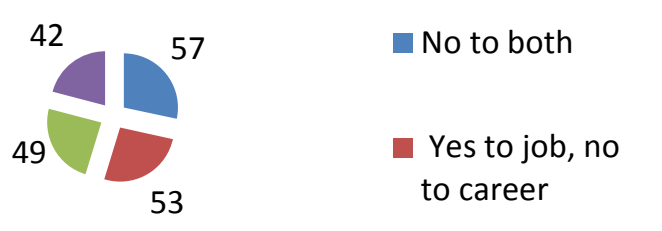

Absence from work in the last six months

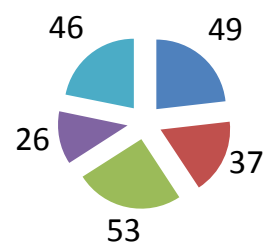
None
1-2 days
1-2 days
4-5 days 
Table-13

Frequency Distribution with respect to Quality of Care

\begin{tabular}{|c|c|c|}
\hline S. No & 'Nursing Retention & Frequency (\%) \\
\hline \multirow[t]{4}{*}{31.} & \multicolumn{2}{|c|}{ The Quality of care on the unit in your last shift } \\
\hline & 1. Improved & 46 \\
\hline & 2. Remained same & 55 \\
\hline & 3. Deteriorated & 110 \\
\hline \multirow[t]{5}{*}{32.} & \multicolumn{2}{|c|}{ The Quality of Nursing care on the unit in your last shift } \\
\hline & 1. Excellent & 57 \\
\hline & 2. Good & 38 \\
\hline & 3. $\quad$ Fair & 38 \\
\hline & 4. Poor & 78 \\
\hline \multirow[t]{3}{*}{35.} & \multicolumn{2}{|c|}{ Medication error in the last six month. } \\
\hline & No & 84 \\
\hline & Yes & 127 \\
\hline
\end{tabular}

Table 13 showed that factors of quality of care by nurses, when asked about The Quality of care on the unit in your last shift 55(26\%) said they found remained same, 57(27\%) answer excellent when asked Quality of Nursing care on the unit in your last shift, $127(60 \%)$ said yes they did error medication in the last six month.

Figure- 15

Quality of Care

1- The Quality of care on the unit in your last shift

\section{The Quality of care on the unit in your last shift}

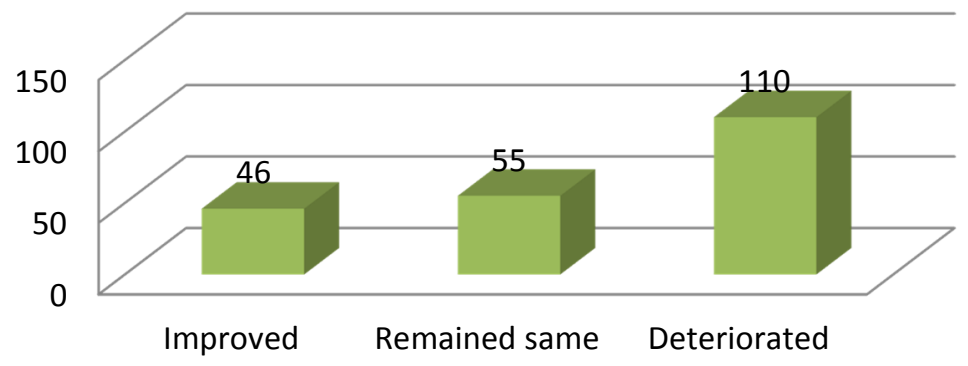

2- The Quality of Nursing care on the unit in your last shift.

\section{The Quality of Nursing care on the unit in your last shift}

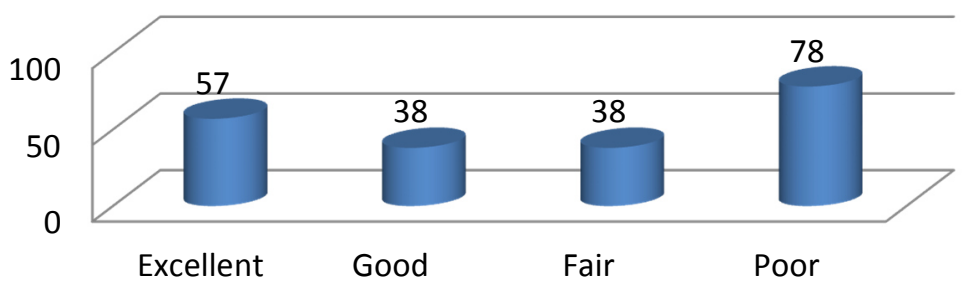


3- Medication error in the last six month

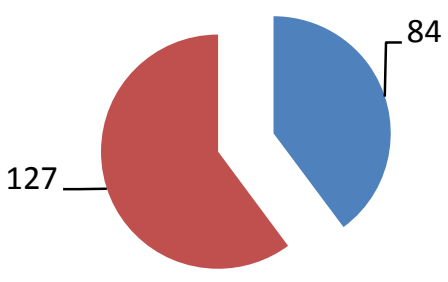

Table 13

Independent Sample t-test for Practices of Nursing Manager

\begin{tabular}{|c|c|c|c|c|c|c|c|c|}
\hline S.No & Practices of Nursing Manager & $\begin{array}{l}\text { Gender } \\
\text { Of Nurses }\end{array}$ & $\mathbf{N}$ & Mean & $\begin{array}{l}\text { Std. } \\
\text { Deviation }\end{array}$ & df & t & Sign \\
\hline \multirow[t]{2}{*}{1.} & \multirow{2}{*}{$\begin{array}{l}\text { My manager seeks out challenging } \\
\text { opportunities that test his/her own skills } \\
\text { and abilities. }\end{array}$} & Male & 40 & 3.20 & 1.285 & \multirow[b]{2}{*}{209} & \multirow{2}{*}{3.153} & \multirow{2}{*}{0.017} \\
\hline & & Female & 171 & 2.87 & 1.470 & & & \\
\hline \multirow[t]{2}{*}{2.} & \multirow{2}{*}{$\begin{array}{l}\text { My manager talks about future trends that } \\
\text { will influence how our work gets done. }\end{array}$} & Male & 40 & 2.42 & 1.279 & \multirow{2}{*}{209} & \multirow[t]{2}{*}{0.545} & \multirow[t]{2}{*}{0.0311} \\
\hline & & Female & 171 & 2.47 & 1.343 & & & \\
\hline \multirow[t]{2}{*}{3.} & \multirow{2}{*}{$\begin{array}{l}\text { My manager develops cooperative } \\
\text { relationships among the people he/she } \\
\text { works with. }\end{array}$} & Male & 40 & 2.98 & 1.561 & \multirow{2}{*}{209} & \multirow{2}{*}{0.081} & \multirow{2}{*}{0.0227} \\
\hline & & Female & 171 & 2.78 & 1.524 & & & \\
\hline \multirow[t]{2}{*}{4.} & \multirow{2}{*}{$\begin{array}{l}\text { My manager sets a personal example of } \\
\text { what he/she expects from others. }\end{array}$} & Male & 40 & 2.75 & 1.463 & \multirow{2}{*}{209} & \multirow[t]{2}{*}{0.020} & \multirow[t]{2}{*}{0.887} \\
\hline & & Female & 171 & 2.85 & 1.431 & & & \\
\hline \multirow[t]{2}{*}{5.} & \multirow{2}{*}{$\begin{array}{l}\text { My manager praises people for a job well } \\
\text { done. }\end{array}$} & Male & 40 & 2.78 & 1.593 & \multirow{2}{*}{209} & \multirow[t]{2}{*}{1.853} & \multirow[t]{2}{*}{0.175} \\
\hline & & Female & 171 & 2.89 & 1.487 & & & \\
\hline \multirow[t]{2}{*}{6.} & \multirow{2}{*}{$\begin{array}{l}\text { My manager challenges people to try out } \\
\text { new and innovative approaches to their } \\
\text { work. }\end{array}$} & Male & 40 & 2.72 & 1.519 & \multirow[b]{2}{*}{209} & \multirow{2}{*}{0.862} & \multirow{2}{*}{0.354} \\
\hline & & Female & 171 & 2.72 & 1.415 & & & \\
\hline \multirow[t]{2}{*}{7.} & \multirow{2}{*}{$\begin{array}{l}\text { My manager describes a compelling } \\
\text { image of what our future could be like. }\end{array}$} & Male & 40 & 3.15 & 1.494 & \multirow{2}{*}{209} & \multirow[t]{2}{*}{0.001} & 0.982 \\
\hline & & Female & 171 & 3.11 & 1.461 & & & \\
\hline 8. & My manager actively listens to diverse & Male & 40 & 3.28 & .784 & 200 & 0.928 & 0.031 \\
\hline & points of view. & Female & 171 & 3.18 & .741 & 207 & & \\
\hline 9. & My manager spends time and energy on & Male & 40 & 3.58 & 1.517 & & & \\
\hline & $\begin{array}{l}\text { making certain that the people he/she } \\
\text { works with adhere to the principles and } \\
\text { standards that have been agreed on. }\end{array}$ & Female & 171 & 3.61 & 1.497 & 209 & 0.015 & 0.902 \\
\hline 10 & My manager makes it a point to let people & Male & 40 & 3.38 & 1.005 & & & \\
\hline & $\begin{array}{l}\text { know about his/her confidence in their } \\
\text { abilities }\end{array}$ & Female & 171 & 3.42 & 1.033 & 209 & 0.225 & 0.036 \\
\hline
\end{tabular}

Table 13 showed that some factors like, "My manager seeks out challenging opportunities that test his/her own skills and abilities", "My manager talks about future trends that will influence how our work gets done", "My manager develops cooperative relationships among the people he/she works with", "My manager actively listens to diverse points of view." and "My manager makes it a point to let people know about his/her confidence in their abilities" are statistically significance level 0.05 practice effect of nursing manager for nurse.

\section{Table 14}

Independent Sample t-test for Practices of Nursing Manager

effect of nursing manager for nurse. 
Table 15

Independent Sample t-test for Practices of Nursing Manager

\begin{tabular}{|c|c|c|c|c|c|c|c|c|}
\hline $\begin{array}{l}\text { S. } \\
\text { No }\end{array}$ & Practices of Nursing Manager & $\begin{array}{l}\text { Gender } \\
\text { Of Nurses }\end{array}$ & $\mathrm{N}$ & Mean & $\begin{array}{l}\text { Std. } \\
\text { Deviation }\end{array}$ & Df & $\mathrm{t}$ & Sign \\
\hline & \multirow{2}{*}{$\begin{array}{l}\text { My manager experiments and takes risks even when } \\
\text { there is a chance of failure }\end{array}$} & Male & 40 & 3.08 & 1.403 & \multirow{2}{*}{209} & \multirow{2}{*}{0.080} & \multirow{2}{*}{0.778} \\
\hline & & Female & 171 & 2.77 & 1.339 & & & \\
\hline & \multirow{2}{*}{$\begin{array}{l}\text { My manager is contagiously enthusiastic and positive } \\
\text { about future possibilities. }\end{array}$} & Male & 40 & 2.92 & 1.309 & \multirow{2}{*}{209} & \multirow{2}{*}{5.561} & \multirow{2}{*}{0.019} \\
\hline & & Female & 171 & 2.89 & 1.546 & & & \\
\hline & \multirow{2}{*}{$\begin{array}{l}\text { My manager gives people a great deal of freedom and } \\
\text { choice in deciding how to do their work. }\end{array}$} & Male & 40 & 2.72 & 1.450 & \multirow{2}{*}{209} & \multirow{2}{*}{.061} & \multirow{2}{*}{0.005} \\
\hline & & Female & 171 & 2.98 & 1.513 & & & \\
\hline & \multirow{2}{*}{$\begin{array}{l}\text { My manager makes certain that we set achievable goals, } \\
\text { make concrete plans, and establish measurable } \\
\text { milestones for the projects and programs that we work } \\
\text { on. }\end{array}$} & Male & 40 & 3.00 & 1.553 & \multirow[b]{2}{*}{209} & \multirow[b]{2}{*}{0.794} & \multirow[b]{2}{*}{0.374} \\
\hline & & Female & 171 & 3.01 & 1.441 & & & \\
\hline & \multirow{2}{*}{ My manager finds ways to celebrate accomplishments } & Male & 40 & 2.92 & 1.439 & \multirow{2}{*}{209} & \multirow{2}{*}{0.690} & \multirow{2}{*}{0.040} \\
\hline & & Female & 171 & 2.91 & 1.483 & & & \\
\hline & \multirow{2}{*}{$\begin{array}{l}\text { My manager takes the initiative to overcome obstacles } \\
\text { even when outcomes are uncertain. }\end{array}$} & Male & 40 & 3.18 & 1.338 & \multirow{2}{*}{209} & \multirow{2}{*}{0.103} & \multirow{2}{*}{0.749} \\
\hline & & Female & 171 & 2.94 & 1.345 & & & \\
\hline & \multirow{2}{*}{$\begin{array}{l}\text { My manager speaks with genuine conviction about the } \\
\text { higher meaning and purpose of our work. }\end{array}$} & Male & 40 & 2.80 & 1.572 & \multirow{2}{*}{209} & \multirow{2}{*}{0.427} & \multirow{2}{*}{0.514} \\
\hline & & Female & 171 & 2.71 & 1.458 & & & \\
\hline & \multirow{2}{*}{$\begin{array}{l}\text { My manager ensures that people grow in their jobs by } \\
\text { learning new skills and developing themselves. }\end{array}$} & Male & 40 & 2.58 & 1.279 & \multirow{2}{*}{209} & \multirow{2}{*}{1.716} & \multirow{2}{*}{0.019} \\
\hline & & Female & 171 & 2.85 & 1.459 & & & \\
\hline & \multirow{2}{*}{$\begin{array}{l}\text { My manager makes progress toward goals one step at a } \\
\text { time. }\end{array}$} & Male & 40 & 2.98 & 1.510 & \multirow{2}{*}{209} & & 0014 \\
\hline & & Female & 171 & 3.08 & 1.372 & & & \\
\hline & My manager gives the members of the team lots of & Male & 40 & 3.32 & 1.509 & & & \\
\hline & & Female & 171 & 3.25 & 1.499 & & & \\
\hline
\end{tabular}

Table 15 showed that some factors like, "manager gives people a great deal of freedom and choice in deciding how to do their work", "manager finds ways to celebrate accomplishments", "manager ensures that people grow in their jobs by learning new skills and developing themselves.", "manager makes progress toward goals one step at a time", are statistically significance level 0.05 practice effect of nursing manager for nurse.

Table 16

Independent Sample t-test for Nursing Retention

\begin{tabular}{|c|c|c|c|c|c|c|c|c|}
\hline S. No & Nursing Retention & $\begin{array}{l}\text { Gender Of } \\
\text { Nurses }\end{array}$ & $\mathbf{N}$ & Mean & $\begin{array}{l}\text { Std. } \\
\text { Deviation }\end{array}$ & df & $\mathbf{t}$ & Sign \\
\hline \multirow{2}{*}{1.} & \multirow{2}{*}{$\begin{array}{l}\text { Intending to leave their job or career in } \\
\text { the next six months. }\end{array}$} & Male & 40 & 2.53 & 1.062 & \multirow{2}{*}{209} & \multirow{2}{*}{0.303} & \multirow{2}{*}{0.583} \\
\hline & & Female & 171 & 2.38 & 1.096 & & & \\
\hline \multirow{2}{*}{2} & \multirow{2}{*}{$\begin{array}{l}\text { Absence from work in the last six } \\
\text { months }\end{array}$} & Male & 40 & 3.05 & 1.632 & \multirow{2}{*}{209} & \multirow{2}{*}{3.034} & \multirow{2}{*}{0.036} \\
\hline & & Female & 171 & 2.89 & 1.408 & & & \\
\hline
\end{tabular}

Table No 16 showed that factor involved in Nursing Retention, Intending to leave their job or career in the next six months is no significant as p-value 0.583 and absence from work in the last six month statistically significant p-value $0.036<0.05$. 
Table 17

Independent Sample t-Test for Quality of Care

\begin{tabular}{|c|c|c|c|c|c|c|c|c|}
\hline S. No & Quality of Care & $\begin{array}{l}\text { Gender } \\
\text { Of Nurses }\end{array}$ & $\mathbf{N}$ & Mean & $\begin{array}{l}\text { Std. } \\
\text { Deviation }\end{array}$ & df & t & Sign \\
\hline \multirow{2}{*}{1.} & \multirow{2}{*}{$\begin{array}{l}\text { The Quality of care on the unit in your } \\
\text { last shift }\end{array}$} & Male & 40 & 2.15 & 0.802 & \multirow{2}{*}{209} & \multirow{2}{*}{0.550} & \multirow{2}{*}{0.459} \\
\hline & & Female & 171 & 2.34 & 0.806 & & & \\
\hline \multirow{2}{*}{2.} & \multirow{2}{*}{$\begin{array}{l}\text { The Quality of Nursing care on the unit } \\
\text { in your last shift. }\end{array}$} & Male & 40 & 2.42 & 1.238 & \multirow{2}{*}{209} & \multirow{2}{*}{0.002} & \multirow{2}{*}{0.004} \\
\hline & & Female & 171 & 2.70 & 1.227 & & & \\
\hline \multirow{2}{*}{3.} & \multirow{2}{*}{ Medication error in the last six month. } & Male & 40 & 1.65 & 0.483 & \multirow{2}{*}{209} & \multirow{2}{*}{2.539} & \multirow{2}{*}{0.113} \\
\hline & & Female & 171 & 1.59 & 0.493 & & & \\
\hline
\end{tabular}

Table No 17 showed that factor involved in quality of care, Quality of Nursing care on the unit in your last shift" is statistically significant $p$-value $0.004<0.05$.

Table 18

One Way ANOVA Test for of Demographic

\begin{tabular}{|c|c|c|c|c|c|c|}
\hline \multicolumn{7}{|l|}{ ANOVA } \\
\hline \multicolumn{2}{|l|}{ Demographic Variables } & $\left|\begin{array}{ll}\text { Sum } & \text { of } \\
\text { Squares } & \end{array}\right|$ & $\mathrm{df}$ & Mean Square & $\mathrm{t}$ & Sig. \\
\hline \multirow[t]{3}{*}{ 1. Gender Of Nurses } & Between Groups & .554 & 5 & .111 & \multirow{3}{*}{.713} & \multirow{3}{*}{0.615} \\
\hline & Within Groups & 31.863 & 205 & .155 & & \\
\hline & Total & 32.417 & 210 & & & \\
\hline \multirow{3}{*}{$\begin{array}{l}\text { 2. Age Group of } \\
\text { Nurses }\end{array}$} & Between Groups & 11.653 & 5 & 2.331 & \multirow{3}{*}{1.528} & \multirow{3}{*}{0.013} \\
\hline & Within Groups & 312.698 & 205 & 1.525 & & \\
\hline & Total & 324.351 & 210 & & & \\
\hline \multirow{3}{*}{$\begin{array}{l}\text { 3. Marital Status of } \\
\text { Nurses }\end{array}$} & Between Groups & 3.174 & 5 & .635 & \multirow{3}{*}{2.714} & \multirow{3}{*}{0.021} \\
\hline & Within Groups & 47.954 & 205 & .234 & & \\
\hline & Total & 51.128 & 210 & & & \\
\hline \multirow{3}{*}{$\begin{array}{l}\text { 4. Qualification } \\
\text { Nurses }\end{array}$} & Between Groups & 20.503 & 5 & 4.101 & \multirow{3}{*}{5.999} & \multirow{3}{*}{0.000} \\
\hline & Within Groups & 140.113 & 205 & .683 & & \\
\hline & Total & 160.616 & 210 & & & \\
\hline \multirow{3}{*}{$\begin{array}{l}\text { 5. Job Experience of } \\
\text { Nurses }\end{array}$} & Between Groups & 11.092 & 5 & 2.218 & \multirow{3}{*}{1.374} & \multirow{3}{*}{0.235} \\
\hline & Within Groups & 330.880 & 205 & 1.614 & & \\
\hline & Total & 341.972 & 210 & & & \\
\hline \multirow{3}{*}{$\begin{array}{l}\text { 6. My Immediate } \\
\text { Supervisor is }\end{array}$} & Between Groups & .225 & 5 & .045 & \multirow{3}{*}{.195} & \multirow{3}{*}{0.964} \\
\hline & Within Groups & 47.206 & 205 & .230 & & \\
\hline & Total & 47.431 & 210 & & & \\
\hline \multirow[t]{3}{*}{ Working } & Between Groups & 10.879 & 5 & 2.176 & \multirow{3}{*}{1.853} & \multirow{3}{*}{0.104} \\
\hline & Within Groups & 240.760 & 205 & 1.174 & & \\
\hline & Total & 251.640 & 210 & & & \\
\hline
\end{tabular}

Table 18 showed that to determine whether any of the differences between the means are statistically significant, compare the p-value to significance level. It is observed that Age, group, marital status, qualifications are statistically significant, as p-value $<0.05$. 
Table 19

Relationship of Nurse Manager's practice with nurse's retention and quality of care among Registered Nurses

Coefficients

\begin{tabular}{|c|c|c|c|c|c|}
\hline \multirow[t]{2}{*}{ Model } & \multicolumn{2}{|c|}{$\begin{array}{l}\text { Unstandardized } \\
\text { Coefficients }\end{array}$} & \multirow{2}{*}{$\begin{array}{l}\text { Standardized } \\
\text { Coefficients } \\
\text { Beta }\end{array}$} & \multirow[t]{2}{*}{$\mathrm{t}$} & \multirow[t]{2}{*}{ Sig. } \\
\hline & $\mathrm{B}$ & Std. Error & & & \\
\hline $\begin{array}{l}\text { 1 (Constant) } \\
\text { Nurse Manager's Practice } \\
\text { Nurse's Retention }\end{array}$ & $\begin{array}{l}8.229 \\
0.443 \\
0.110\end{array}$ & $\begin{array}{l}0.716 \\
0.006 \\
.0 .060\end{array}$ & $\begin{array}{r}0.112 \\
0.417\end{array}$ & $\begin{array}{r}12.204 \\
0.165 \\
6.542\end{array}$ & $\begin{array}{l}.000 \\
.002 \\
.003\end{array}$ \\
\hline
\end{tabular}

Table19 showed that P-value significant and Standardized coefficient beta 0.112 and 0.417 that's mean all variables of Nurse Manager's Practice and Nurse's Retention effect at11.2\%.and 41.7\% respectively.

\section{Discussion:}

The focus of this research was to identify the relationship of nurse manager's practices with nurse's retention and quality of care among registered nurses. A detailed organizational evaluation and the results of the survey provided an understanding of the existing culture and behavior of the nurse manager. These evaluation findings confirmed the need to develop a leadership role in nursing, especially in the areas of relationship building and empowerment of nurses. While some disagreed, a preponderance of the literature supported the impact that positive nursing relationships and work environment empowerment had on registered nurse restraint and better patient care. The current study showed the mean age of participants was $28.00 \pm 2.81$ years old, it was observed that mostly participants of the study was female as $91 \%$ and male were only $9 \%$. Mostly participant were young $126(60 \%)$ having age group 20-30 years, 171(81) participants were female as compare with male was 40(19\%). The ratio of married $124(59 \%)$ high as $87(41 \%)$ were unmarried. According to their professional qualification $79(37 \%)$ having diploma in general nursing and midwifery, 68(32\%) educated at Specialization level as compare with 58(28\%) have Post RN/BSCN and only 6(3\%) nurses have MSN level education in nursing. Regarding their working experience; $85(40.3 \% \%)$ have maximum working experience 2-6 years, $49(23.2 \%)$ have experience $7-11$ years as compare with $37(17.4 \%)$ have work experience from 12 to 16 years, 26(12.3\%) worked maximum 17-21 years while 14(6.6) having 22-26 years. 72(34.1\%) working as registered nurse and $139(65.9 \%)$ performing head nurse as a supervisor. A study conducted Bormann, Lorraine B (2014), he found that the demographic profile of the sample included the greatest percentage of staff nurses $(21.7 \%)$ were in the age group of 26-30 years of age followed by age group $41-45$ (15.7\%). This study found that $27.8 \%$ of staff RNs were older than 50 years with an average age of 42 years. Same results reported by Buerhaus, $\mathrm{P}$ and Auerbach (2016).In his projected the average age of registered nurses to 44.5 by 2012 and almost one quarter of the registered nurses population being in their $50 \mathrm{~s}$. The respondents in this study were younger average age but greater percentage over 50 years of age than the Anderson, Bet al. (2014) report. To access the factors of nursing manage practice, it was observed that 55(26.01\%) almost never that manager seeks out challenging opportunities that test his/her own skills and abilities , 74(35.07\%) manager talks about future trends that will influence how our work gets done almost never ,65(30.8\%) manager develops cooperative relationships among the people he/she works almost never , 53(25.1\%) . almost never manager sets a personal example of what he/she expects from others, 59(28\%) manager challenges people to try out new and innovative approaches to their work, 52(25\%) almost always manager describes a compelling image of what our future could be like, $84(40 \%)$. Seldom and very frequently manager actively listens to diverse points of view, $84(40 \%)$ almost always manager spends time and energy on making certain that the people he/she works with adhere to the principles and standards that have been agreed on., 84(40\%) seldom manager makes it a point to let people know about his/her confidence in their abilities, . 84(40\%) almost frequently manager searches outside the formal boundaries of our organization for innovative ways to improve what we do, 84(40\%). Very frequent and almost always manager appeals to others to share an exciting dream of the future, $211(100 \%)$ manager seldom treats others with dignity and respect , 169(81\%) very frequently manager follows through on the promises and commitments that he/she makes., $127(60 \%)$ almost always manager makes sure that people are creatively rewarded for their contributions to the success of our projects. Nurses' retention is an important priority of nursing administration. Research in business and industry has shown that management practices were related to retention. This research describes how practice of nurse manager is directly related to expected retention of nurses working in inpatients units. The current study showed that factors of nursing retention, 57(27\%) said no to both when asked about Intending to leave their job or career in the next six months , 53(23\%) absence from work in the last six months.. These findings were supported by a study of full-time nurses in the inpatient units by Boswell S, Wilhoit K. (2014), who pointed out that the majority of respondents perceived that their manager who has worked with them showed an advisory leadership practice. This was demonstrated by use of nurse's ideas, opinions and their 
active involvement in decision making. In this issue, Laschinger HK (2014), supported this finding and noted that the participants perceived a positive relationship between the ability to consult with the leader and substantive trust. The current study focused on factors of quality of care by nurses, when asked about The Quality of care on the unit in your last shift 55(26\%) said they found remained same, 57(27\%) answer excellent when asked Quality of Nursing care on the unit in your last shift , 127(60\%) said yes they did error medication in the last six month. The research conducted by Spence Laschinger and Heather K (2015), The aim of their research is to evaluate the model of nursing work of Leiter and Laschinger, which combines structural empowerment with the 5-factor model of professional practice of Lake and the quality of work results, A predictive and non-experimental design was used to test the model in a sample of 234 nurses. The analysis found that the characteristics of the occupational practice environment mediated the relationship between structurally empowering working conditions and job satisfaction and the quality of nurse-rated patient care.

\section{Conclusion}

The present study is considered as a cornerstone that gives strong support towards understanding of nurses' manager and their retention. It highlighted that a significant difference was found between management styles with nurse' retention and patient care. These results substantiate the belief that aspects of the practice environment affect staff nurse retention, and most importantly, the quality of care delivered on hospital nursing units.

\section{Strength of the study :}

The present study has a number of strength which are as follow:

1) This is a first study conducted in Public Hospital of Pakistani context which assessed the relationship on nurse manager's practices with nurse's retention and quality of care. Moreover, this study has gathered rich data on knowledge and practices variables along with the demographic variables simultaneously.

2) In this study the questioner tool was used, which was already been tested for validity and reliability.

3) The large sample size i.e, 211 in this study also enhanced the internal validity of the research.

4) Data collected in the supervision and accurate information was collected.

\section{Limitation}

The study has certain limitations that need to be acknowledged in the interpretation of the result.

1) This is a cross-sectional study, therefore inferences related to the causality of association could not be draw, however, case control and cohort studies should be conducted to establish causal relationship.

2) As the data is collected from only one setting, it has limited generalizability.

3) Convenient sampling was applied in data collection process whereas the probability sampling method can enhance the induction of different strata of the participants.

4) The study is limited to assess the relationship of nurse manager's practices with nurse's retention and quality of care.

\section{Recommendation}

Based on the study results, the following strategies are recommended in order to develop Nurse's retention through:

- Hospital leaders should plan and implement effective strategies to promote nurses' retention.

- Creating a more supportive professional nursing practice that allows nurses to practice to their full opportunities for professional interactions. This can be done through the development of a clinical ladder for advancement within the organization.

- Motivating nurses through providing job enrichment and developing reward systems for nurses based on their workloads.

- Improving the image of nursing profession through effective marketing, good media, as well as emphasizing the actual role of mercy angels.

- Creating opportunities to attract and retain nurses by strengthening the interpersonal leadership and management skills within the hospital.

- Enhancing a positive work environment through promotion of teamwork, encouraging continuous education, trust, respect and flexible scheduling.

\section{References}

Aiken, L. H., Sermeus, W., Van den Heede, K., Sloane, D. M., Busse, R., McKee, M., . . Moreno-Casbas, M. T. (2012). Patient safety, satisfaction, and quality of hospital care: cross sectional surveys of nurses and patients in 12 countries in Europe and the United States. Bmj, 344, e1717.

Alreshidi, T. (2016). Registered nurses perceptions of medication administration errors and their management in Saudi Arabian hospitals. University Of salford.

Alsulami, Z., Conroy, S., \& Choonara, I. (2013). Medication errors in the Middle East countries: a systematic 
review of the literature. European journal of clinical pharmacology, 69(4), 995-1008.

Anderson, D. J., \& Webster, C. S. (2001). A systems approach to the reduction of medication error on the hospital ward. Journal of advanced nursing, 35(1), 34-41.

Barker, K. N., Flynn, E. A., Pepper, G. A., Bates, D. W., \& Mikeal, R. L. (2002). Medication errors observed in 36 health care facilities. Archives of internal medicine, 162(16), 1897-1903.

Cascio, W. F. (2014). Leveraging employer branding, performance management and human resource development to enhance employee retention: Taylor \& Francis.

Duffield, C., Roche, M., O’Brien-Pallas, L., Catling-Paull, C., \& King, M. (2014). Staff satisfaction and retention and the role of the nursing unit manager. Collegian, 16(1), 11-17.

Duffield, C. M., Roche, M. A., Blay, N., \& Stasa, H. (2011). Nursing unit managers, staff retention and the work environment. Journal of clinical nursing, $20(1-2), 23-33$.

Ehsani, S. R., Cheraghi, M. A., Nejati, A., Salari, A., Esmaeilpoor, A. H., \& Nejad, E. M. (2013). Medication errors of nurses in the emergency department. Journal of medical ethics and history of medicine, 6.

Eisler, K. (2009). The leadership practices of nurse managers and the association with nursing staff retention and the promotion of quality care in two Saskatchewan hospitals.

El-Jardali, F., Dimassi, H., Dumit, N., Jamal, D., \& Mouro, G. (2009). A national cross-sectional study on nurses' intent to leave and job satisfaction in Lebanon: implications for policy and practice. BMC nursing, $8(1), 3$.

Finkler, S. A., Kovner, C. T., \& Jones, C. B. (2007). Financial management for nurse managers and executives: Elsevier Health Sciences.

Flinkman, M., Isopahkala-Bouret, U., \& Salanterä, S. (2013). Young registered nurses' intention to leave the profession and professional turnover in early career: a qualitative case study. ISRN nursing, 2013.

Friese, C. R., Lake, E. T., Aiken, L. H., Silber, J. H., \& Sochalski, J. (2008). Hospital nurse practice environments and outcomes for surgical oncology patients. Health services research, 43(4), 1145-1163.

Hamid, S., Malik, A. U., Kamran, I., \& Ramzan, M. (2014). Job satisfaction among nurses working in the private and public sectors: a qualitative study in tertiary care hospitals in Pakistan. Journal of multidisciplinary healthcare, 7, 25.

Heidari, M., Seifi, B., \& Gharebagh, Z. A. (2017). Nursing staff retention: Effective factors. Annals of Tropical Medicine and Public Health, 10(6), 1467.

Holmström, A.-R. (2017). Learning from Medication Errors in Healthcare How to Make Medication Error Reporting Systems Work?

Hughes, V. (2017). Leadership Strategies to Promote Nurse Retention.

Källander, K., Tibenderana, J. K., Akpogheneta, O. J., Strachan, D. L., Hill, Z., ten Asbroek, A. H., .. . Meek, S. R. (2013). Mobile health (mHealth) approaches and lessons for increased performance and retention of community health workers in low-and middle-income countries: a review. Journal of medical Internet research, 15(1).

Karmel, T., \& Li, J. (2002). The nursing workforce-2010: Department of Education, Science and Training.

Kouzes, J. M., \& Posner, B. Z. (2001). Bringing leadership lessons from the past into the future.

Kovane, M. (2015). Factors causing absenteeism of nurses in an acute psychiatric hospital: case study in Cape Town.

Kramer, M., Schmalenberg, C., \& Maguire, P. (2010). Nine structures and leadership practices essential for a magnetic (healthy) work environment. Nursing Administration Quarterly, 34(1), 4-17.

Lambrou, P., Merkouris, A., Middleton, N., \& Papastavrou, E. (2014). Nurses' perceptions of their professional practice environment in relation to job satisfaction: a review of quantitative studies.

McGuire, E., \& Kennerly, S. M. (2006). Nurse managers as transformational and transactional leaders. Nursing Economics, 24(4), 179.

Mrayyan, M. (2006). Jordanian nurses' job satisfaction, patients' satisfaction and quality of nursing care. International nursing review, 53(3), 224-230.

Mudaly, P., \& Nkosi, Z. (2015). Factors influencing nurse absenteeism in a general hospital in Durban, South Africa. Journal of Nursing Management, 23(5), 623-631.

Nassar, M. E., Abdou, H. A., \& Mohmoud, N. A. (2011). Relationship between management styles and nurses' retention at private hospitals. Alexandria Journal of Medicine, 47(3), 243-249.

Needleman, J., Buerhaus, P., Mattke, S., Stewart, M., \& Zelevinsky, K. (2015). Nurse-staffing levels and the quality of care in hospitals. New England Journal of Medicine, 346(22), 1715-1722.

O’Brien - Pallas, L., Meyer, R. M., Hayes, L. J., \& Wang, S. (2011). The Patient Care Delivery Model-an open system framework: conceptualisation, literature review and analytical strategy. Journal of Clinical Nursing, $20(11$ - 12), 1640-1650.

Parahoo, K. (2014). Nursing research: principles, process and issues: Palgrave Macmillan.

Park, M., \& Jones, C. B. (2010). A retention strategy for newly graduated nurses: an integrative review of orientation programs. Journal for Nurses in Professional Development, 26(4), 142-149. 
Phaneuf, M. C. (1976). The nursing audit: Self-regulation in nursing practice: Appleton-Century-Crofts.

Ross, J. (2017). Organizational Support, Workload, and Intent to Stay: Work Environment Perceptions in Perianesthesia Nursing Units. Journal of PeriAnesthesia Nursing, 32(4), 287-294.

Shuldham, C., Parkin, C., Firouzi, A., Roughton, M., \& Lau-Walker, M. (2015). The relationship between nurse staffing and patient outcomes: a case study. International journal of nursing studies, 46(7), 986-992.

Slovin, E. (1960). Slovin's formula for sampling technique. Retrieved on February, 13, 2013.

Ulrich, B., Krozek, C., Early, S., Ashlock, C. H., Africa, L. M., \& Carman, M. L. (2010). Improving retention, confidence, and competence of new graduate nurses: Results from a 10-year longitudinal database. Nursing Economics, 28(6), 363.

Van den Heede, K., Florquin, M., Bruyneel, L., Aiken, L., Diya, L., Lesaffre, E., \& Sermeus, W. (2013). Effective strategies for nurse retention in acute hospitals: a mixed method study. International journal of nursing studies, 50(2), 185-194.

Wensing, M., Wollersheim, H., \& Grol, R. (2006). Organizational interventions to implement improvements in patient care: a structured review of reviews. Implementation science, 1(1), 2.

Wong, C. A., Cummings, G. G., \& Ducharme, L. (2013). The relationship between nursing leadership and patient outcomes: a systematic review update. Journal of Nursing Management, 21(5), 709-724.

Wong, C. A., SPENCE LASCHINGER, H. K., \& Cummings, G. G. (2010). Authentic leadership and nurses' voice behaviour and perceptions of care quality. Journal of Nursing Management, 18(8), 889-900.

Yang, Y., Liu, Y.-H., Liu, J.-Y., \& Zhang, H.-F. (2015). The impact of work support and organizational career growth on nurse turnover intention in China. International Journal of Nursing Sciences, 2(2), 134-139. 